EUROPEAN CRIME FICTIONS

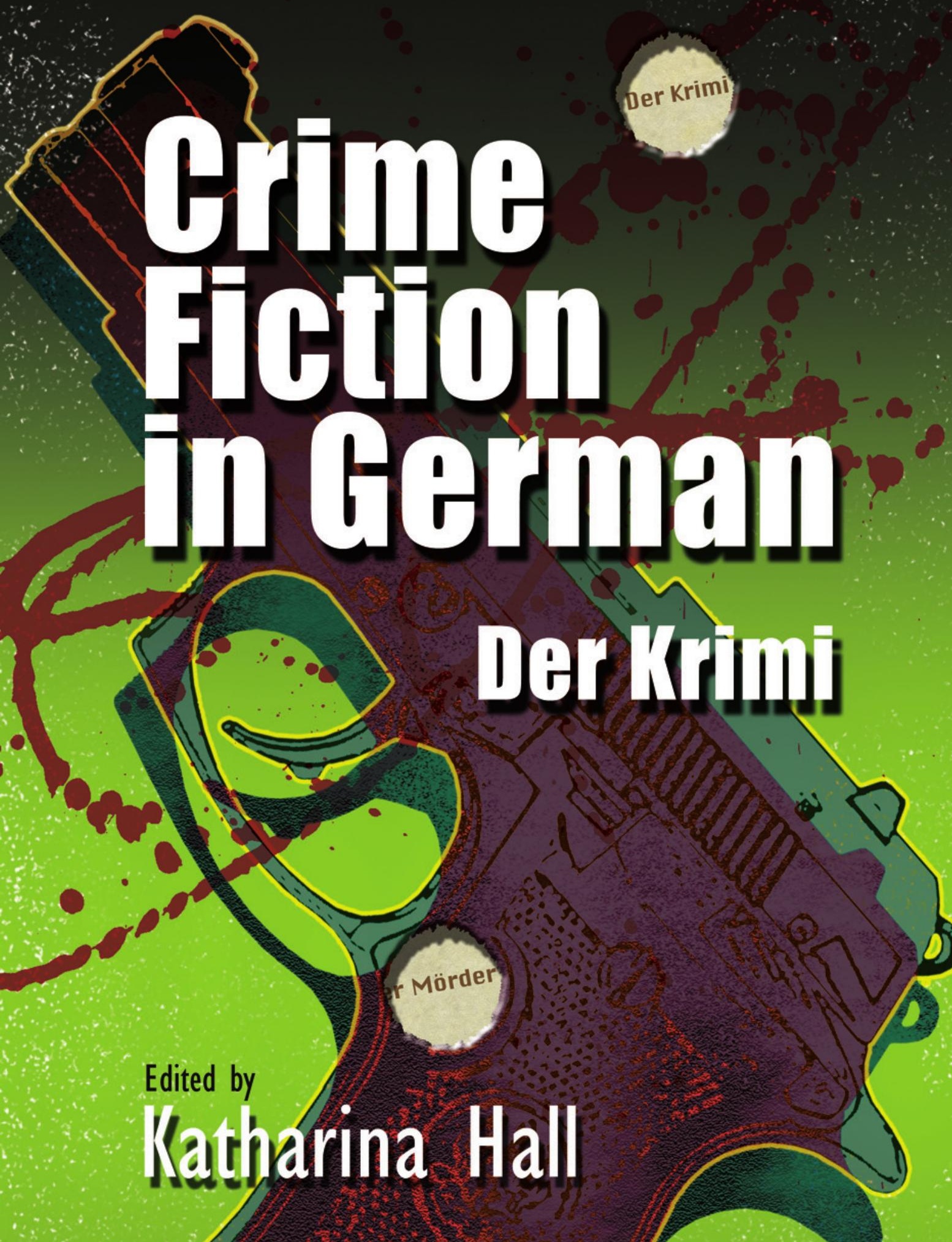


Series Editors

Claire Gorrara (Cardiff University)

Shelley Godsland (University of Birmingham)

Giuliana Pieri (Royal Holloway, London)

\section{Editorial Board}

Margaret Atack (University of Leeds)

George Demko (Dartmouth College)

John Foot (University College London)

Stephen Knight (University of Melbourne)

Nickianne Moody (Liverpool John Moores University)

Elfriede Müller (Berlin)

Anne White (University of Bradford)

Also in Series

Claire Gorrara (ed.)

French Crime Fiction

Andrew Nestingen and Paula Arvas (eds)

Scandinavian Crime Fiction

Nancy Vosburg (ed.)

Iberian Crime Fiction

Guiliana Pieri (ed.)

Italian Crime Fiction

Lucy Andrew and Catherine Phelps (eds)

Crime Fiction in the City: Capital Crimes 
EUROPEAN CRIME FICTIONS

\section{CRIME FICTION IN GERMAN \\ DER KRIMI}

Edited by

Katharina Hall

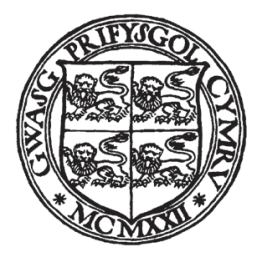

CARDIFF

2016 
All rights reserved. No part of this book may be reproduced in any material form (including photocopying or storing it in any medium by electronic means and whether or not transiently or incidentally to some other use of this publication) without the written permission of the copyright owner except in accordance with the provisions of the Copyright, Designs and Patents Act. Applications for the copyright owner's written permission to reproduce any part of this publication should be addressed to the University of Wales Press, 10 Columbus Walk, Brigantine Place, Cardiff, CF10 4UP.

www.uwp.co.uk

British Library Cataloguing-in-Publication Data

A catalogue record for this book is available from the British Library.

$\begin{array}{ll}\text { ISBN } & 978-1-78316-816-3(\mathrm{hb}) \\ & 978-1-78316-817-0(\mathrm{pb}) \\ \text { e-ISBN } & 978-1-78316-818-7\end{array}$

The right of the Contributors to be identified as authors of their contributions has been asserted by them in accordance with sections 77 and 79 of the Copyright, Designs and Patents Act 1988.

\section{DOI $\quad 10.16922 / 1783168163-01$}

The chapter 'Crime Fiction in German: Concepts, Developments and Trends' by Katharina Hall is funded by Swansea University for publication under a Creative Commons Attribution Non-commercial Non-derivative International licence (CC BY-NC-ND). This licence allows you to share, copy, distribute and transmit the work for personal and non-commercial use providing author and publisher attribution is clearly stated; this chapter is also available at https:// cronfa.swan.ac.uk/Record/cronfa25191

Further details about CC BY licences are available at http://creativecommons.org/licenses/

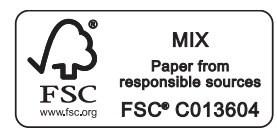

Typeset in Wales by Eira Fenn Gaunt, Cardiff

Printed in Great Britain by CPI Antony Rowe, Chippenham, Wiltshire 


\section{Contents}

Acknowledgements vii

Notes on Contributors $\quad$ ix

Map of German-speaking Areas in Europe xi

Chronology of Crime Fiction in German xii

1 Crime Fiction in German: Concepts, Developments and Trends 1

- Der Krimi

- The pioneers (1828-1933)

- Crime fiction under National Socialism (1933-45)

- Early post-war crime narratives (1945-60) and East German crime fiction (1949-71)

- The West German Soziokrimi (1960-) and later East German crime fiction (1971-89)

- Turkish-German crime fiction and the Frauenkrimi (1980-)

- Historical crime fiction, regional crime fiction and the rise of the Afrika-Krimi (1989-)

- Crime fiction of the new millennium and the lacuna of JewishGerman crime fiction

\section{Katharina Hall}

2 The Emergence of Crime Fiction in German: an Early Maturity Mary Tannert

3 Austrian Crime Fiction: Experimentation, Critical Memory and Humour

Marieke Krajenbrink

4 Swiss Crime Fiction: Loosli, Glauser, Dürrenmatt and Beyond

Martin Rosenstock

5 Der Afrika-Krimi: Africa in German Crime Fiction Julia Augart 
6 Der Frauenkrimi: Women's Crime Writing in German Faye Stewart

7 Historical Crime Fiction in German: the Turbulent Twentieth Century 115 Katharina Hall

8 Der Fernsehkrimi: an Overview of Television Crime Drama in German 132 Katharina Hall

Annotated Bibliography of Resources on German-language Crime

Narratives

Katharina Hall

Index 


\section{Notes on Contributors}

Julia Augart is Senior Lecturer in German at the University of Namibia. She received her PhD in German literature in 2004 from the University of Freiburg, Germany, on Clemens Brentano and Sophie Mereau. She has held various teaching positions at Yale University, Trinity College (USA), Freiburg University and as a DAAD-Lecturer at Kenyatta University (Kenya) and Stellenbosch University (South Africa). She has published widely on German literature, Africa in German literature and also on German crime fiction set in Africa. She is currently working on a book on Africa in German crime fiction.

Katharina Hall is Associate Professor of German at Swansea University, Wales. She has published widely on representations of the history and memory of National Socialism in the works of Günter Grass, Esther Dischereit and Bernhard Schlink. Her current project, 'Detecting the Past', explores transnational, Nazi-themed crime fiction from 1945 to the present day, with recent articles on representations of German wartime suffering and the 'Nazi detective'. A member of Swansea's Centre for Contemporary German Culture, she also runs the international crime fiction blog 'Mrs Peabody Investigates' (http://mrspeabodyinvestigates. wordpress. $\mathrm{com} /)$.

Marieke Krajenbrink is Lecturer in German and Course Director of the MA in Comparative Literature and Cultural Studies at the University of Limerick. She has published on German and Austrian crime fiction, intertextuality and intermediality, and representations of cultural identity in literature. She is the author of Intertextualität als Konstruktionsprinzip. Transformationen des Kriminalromans und des romantischen Romans bei Peter Handke und Botho Strau $\beta$ (Amsterdam and Atlanta, GA: Rodopi, 1996), and co-editor, with Kate Quinn, of Investigating Identities: Questions of Identity in Contemporary International Crime Fiction (Amsterdam and New York: Rodopi, 2009). A founding member of the International Crime Genre Research Network, Ireland, she is currently working on a project on 'Consuming Crime'.

Martin Rosenstock is Assistant Professor of German at Gulf University for Science and Technology in Kuwait. He received his PhD in German literature in 2008 
from the University of California, Santa Barbara. Prior to his appointment at GUST in 2011, he held visiting positions at Iowa State University and the University of Connecticut. He has published on the depiction of crime and detective work in German, English and American culture. He is currently working on a book project that investigates the portrayal of failed detectives in German-language literature. Recently, he published a co-edited volume of essays on German-East Asian encounters.

Faye Stewart is Associate Professor of German at Georgia State University, where she is also affiliated with the Institute for Women's, Gender and Sexuality Studies and the Center for Human Rights and Democracy. Her teaching and research interests are twentieth- and twenty-first-century German literature and film, gender and sexuality studies, and transnationalism, justice and human rights. Publications include the book German Feminist Queer Crime Fiction: Politics, Justice and Desire (Jefferson, NC: McFarland, 2014) and several articles on mystery fiction. She is currently working on projects on Antje Rávic Strubel, Islam in contemporary Germany and depictions of the death penalty.

Mary Tannert's interest in the history of German-language crime fiction dates to her doctoral work in the early 1990s and her dissertation on Auguste Groner. Her publications include the anthology Early German and Austrian Detective Fiction, which she translated and edited with Henry Kratz (Jefferson: McFarland \& Company, Inc., 1999), several articles on early German-language crime fiction for Lexikon der Kriminalliteratur and more than twenty-five translated short crime stories for Ellery Queen's Mystery Magazine. She works as a freelance translator of marketing, legal and financial texts as well as contemporary German-language crime fiction. 


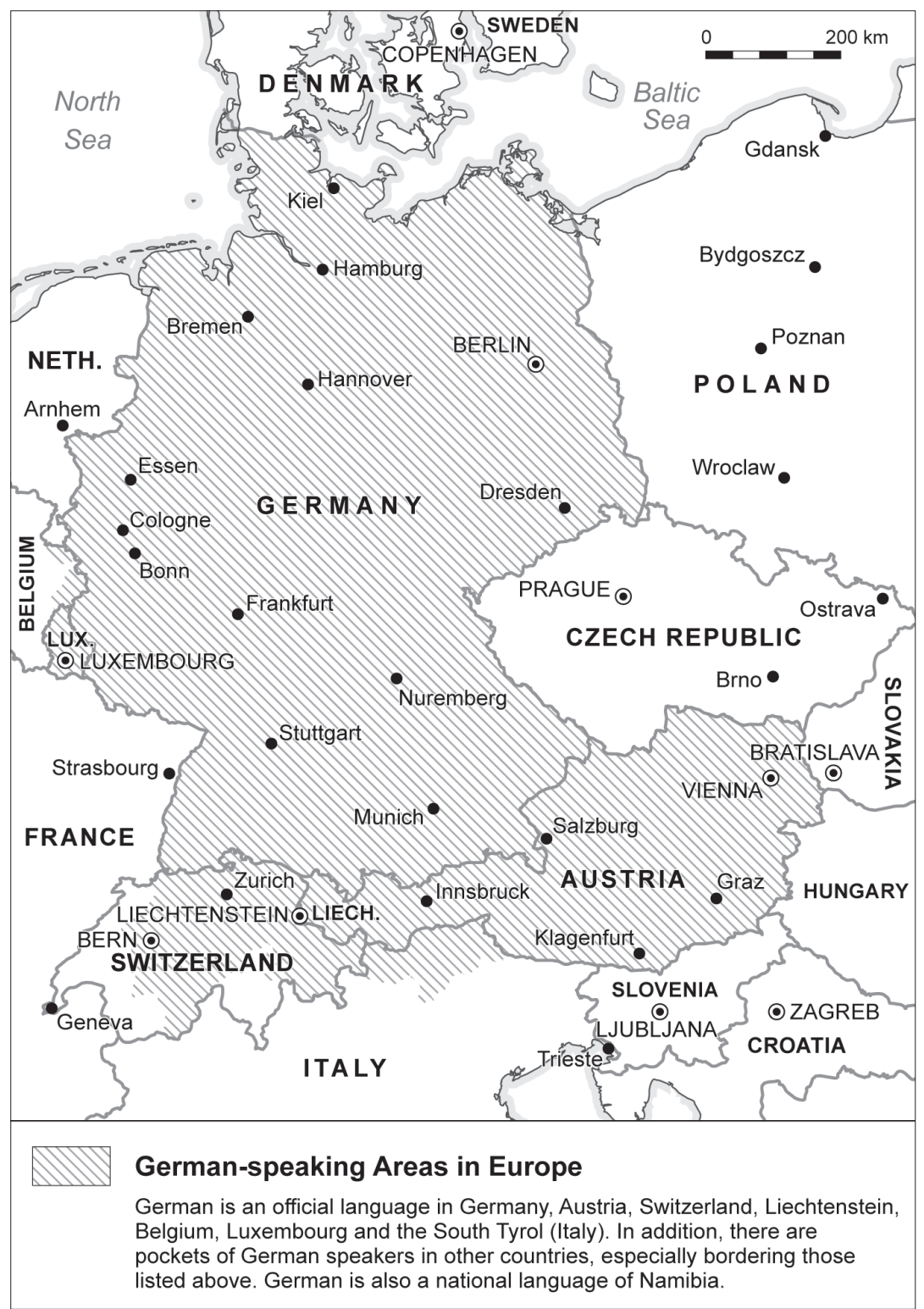




\title{
1 \\ Crime Fiction in German: Concepts, Developments and Trends
}

\author{
KATHARINA HALL
}

Undoubtedly, the crime novel displays all the characteristics of a flourishing branch of literature. ${ }^{1}$

This volume, which forms part of the University of Wales Press 'European Crime Fictions' series, is the first in English to offer a comprehensive overview of Germanlanguage crime fiction from its origins in the early nineteenth century to the postreunification Germany of the new millennium. Its primary aim is to introduce readers to key areas of crime fiction from the German-speaking world through this and subsequent chapters on early German-language crime, Austrian crime, Swiss crime, the Afrika-Krimi (German-language crime novels set in Africa or with African characters and themes), the Frauenkrimi (crime written by, about and for women) and twentieth-century historical crime. An additional aim is to highlight the richness of German-language crime fiction and to provide readers with a springboard for further reading, viewing and research. To this end, our understanding of the crime genre is purposefully broad, allowing hybrid crime narratives by literary authors to be considered, and relevant links to be made to films and the highly popular Fernsehkrimi (television crime drama), which is explored in chapter 8 . A significant percentage of the crime narratives under discussion are already published in English, thus providing the non-German speaker with opportunities to access works (where a novel's English title is italicized, this indicates that the text has appeared in translation). ${ }^{2}$ Chapters conclude with an English-language extract to showcase a primary text, as well as providing bibliographies of core primary and secondary materials. A substantial annotated bibliography at the end of the volume directs readers towards further Germanand English-language resources.

More broadly, the volume aims to expand the notion of a German-language crime-writing tradition, drawing inspiration from publishers such as Edition Köln, which is reprinting forgotten early works, and from academic studies by contemporary scholars in the German- and English-speaking worlds, which are successfully illuminating neglected areas of research. Until remarkably recently, it was argued either that Germany had no proper tradition of crime fiction or that German crime fiction only came into being in the 1960s, when authors supposedly 
started to write crime narratives set in Germany that engaged with specifically German concerns. ${ }^{3}$ These claims gained purchase due to a complex set of factors: a deeply entrenched distinction between $U$-und E-Literatur (entertaining literature and serious literature), ${ }^{4}$ whose codified notions of quality discouraged research on so-called Trivialliteratur (trivial literature) $;{ }^{5}$ German academia's disinclination, even once crime fiction became a more legitimate area of study in the $1970 \mathrm{~s},{ }^{6}$ to explore its own crime fiction heritage, focusing instead on Edgar Allan Poe, Arthur Conan Doyle and British Golden Age writers; ${ }^{7}$ and a self-perpetuating acceptance of the critical status quo until a post-reunification generation of researchers began to reassess the field in the 1990s. As a result, important examples of German crime fiction were often ignored, such as Hans Fallada's Jeder stirbt für sich allein (Alone in Berlin, 1947), as indeed were entire phases of crime fiction production, such as under National Socialism (1933-45). ${ }^{8}$ As recently as 2008, Edition Köln's publicity slogans for two series reissuing neglected primary works were as follows: 'German-language crime fiction has no tradition? True. But it could have one' and 'Edition Köln - the publisher that's writing (crime) history'.'

In addition, a narrow critical focus on German crime fiction as 'crime fiction from Germany' rather than 'crime fiction in German' has tended to minimize the contribution of Swiss, Austrian and East German crime narratives to a Germanlanguage crime writing tradition. ${ }^{10}$ The scholarly separation of Germany's crime fiction from that of other German-speaking countries may reflect certain value judgements (that they are 'minor' crime corpora due to the small size of the countries concerned and/or the negative assessment of their literary worth),${ }^{11}$ or an overzealous attitude to scholarly categorization (wishing to keep the outputs of different nations separate). However, a Germany-centred approach is limiting, because it excludes seminal crime novels and misses the opportunity to trace the similarities, differences and dialogues between the crime fiction of the four countries. ${ }^{12}$ Obvious examples are the Swiss crime novels of Friedrich Glauser and Friedrich Dürrenmatt, which portray the Switzerland of the 1930s and 1950s, but also address the country's uneasy relationship with Germany before, during and after National Socialism. Both authors have also undoubtedly had a lasting influence in and beyond the German-speaking world. Accordingly, this volume includes chapters on crime fiction in specific national contexts, exploring the distinctive features of German, Austrian and Swiss crime, but also offers an integrated overview of German-language crime fiction in the 'Chronology of Crime Fiction in German' and in the chapter that follows.

This chapter will examine key terminology relating to crime fiction in German and provide a diachronic overview of its development. Spatial constraints prohibit an exhaustive survey: Jockers and Jahn's 2005 Lexikon der deutschsprachigen KrimiAutoren (Encyclopedia of German-language Crime Authors) contains 600 contemporary writer entries alone, most of whom have authored multiple works. The aim is rather to highlight important texts and trends, alongside industry and publishing milestones. Particular attention is paid to areas that are touched on, but not covered in detail in other chapters, such as National Socialist and East 
German crime fiction, the 1970s Soziokrimi (social crime novel) and TurkishGerman crime fiction. In common with the volume's other chapters, the overview draws on a wide range of German- and English-language criticism, and places its discussion in the larger contexts of social, political and historical events.

\title{
Der Krimi
}

The crime novel is affectionately known as der Krimi in the German-speaking world - an abbreviation of the noun der Kriminalroman (the crime novel) - and is used as shorthand to describe all varieties of crime novel from the psychological thriller to the police procedural. However, it is worth noting a long-standing distinction between the Kriminalroman and the Detektivroman (the detective novel) in the reception of German-language crime fiction, which allows an appreciation of different narrative approaches taken by crime authors. Definitions vary from critic to critic, but Richard Alewyn provides the following summation: 'the Kriminalroman tells the story of a crime; the Detektivroman tells the story of the solving of a crime'. ${ }^{13}$ As Heinrich Henel usefully elaborates,

\begin{abstract}
the crime narrative first acquaints the reader with the perpetrator, then with the crime, and lastly with the consequences of the crime; it is interested in the psychological developments that led to the crime . . . The detective narrative is the opposite. It begins with the discovery of the body, reconstructs the crime using clues and tracks down the criminal at the end; it is interested in the intellectual work of the detective, so that the perpetrator's motives only function as clues or as a means of securing the legal aspects of the case. ${ }^{14}$
\end{abstract}

An example of the Kriminalroman in its purest form is Ingrid Noll's satirical crime novel Die Apothekerin (The Pharmacist, 1994), in which a perpetrator relates the story of a series of murders, with the police playing a minor role. The first quarter of the narrative focuses on the events leading up to the first murder and explores the murderer's motivation, thereby contrasting with a Detektivroman such as Jakob Arjouni's Happy Birthday, Türke! (Happy Birthday, Turk!, 1987), which shows the crime at the beginning of the narrative, and only reveals the perpetrator and motive through the rational deductions of the detective at its end. The Detektivroman is often explored by German critics through reference to classic detective narratives and iconic detectives (Poe's Dupin, Conan Doyle's Holmes, Georges Simenon's Maigret and Agatha Christie's Poirot),${ }^{15}$ but applies equally to later police-led investigations (such as Nele Neuhaus's 'Bodenstein and Kirchhoff' series, 2006-), or noir detective fiction featuring private investigators (such as Arjouni's 'Kayankaya' series, 1987-2012). Predominantly, the distinction between the two types of narrative rests on the perspective from which it is told - that of the perpetrator or the investigator. However, it is entirely possible for crime narratives to carry elements of both approaches through the adoption of a 
dual perspective, thereby creating hybrid forms, as seen in Jan Costin Wagner's 'Kimmo Joentaa' series (2003-), which alternates between the perpetrator's and the policeman's point of view, and pays detailed attention to the psychology of both.

A number of subgenres are referenced in discussions of German-language crime fiction, many of which draw on other national crime-writing traditions. Examples include the Rätselkrimi (puzzle crime novel), influenced by British Golden Age writers such as Christie $;{ }^{16}$ the Soziokrimi (social crime novel), shaped by Swedish authors Maj Sjöwall and Per Wahlöö, ${ }^{17}$ the Polizeikrimi (police novel/ police procedural), which draws on Simenon's Belgian 'Maigret' series, the French roman policier and the works of Sjöwall and Wahlöö; ${ }^{18}$ the Frauenkrimi, which grew from the work of Anglo-American authors such as Sara Paretsky and Val McDermid; ${ }^{19}$ der psychologische Krimi or Psychothriller (psychological crime novel/ thriller), influenced by American author Patricia Highsmith, ${ }^{20}$ and the Privatermittler (private investigator) crime narrative, which emerged belatedly from the hard-boiled tradition of Hammett and Chandler. ${ }^{21}$ Unsurprisingly, given the rich and turbulent history of German-speaking countries, der historische Krimi (historical crime novel) ${ }^{22}$ also plays a prominent role, particularly in post-1945 crime fiction. These subgenres frequently overlap with one another, making rigid categorization impossible and undesirable: for example, a historical crime novel such as Richard Birkefeld and Göran Hachmeister's Wer übrig bleibt, hat recht (To the Victor the Spoils, 2002) also contains elements of the police novel and psychological crime. Hybrid crime novels by 'literary' authors must also be acknowledged, as they constitute some of the most powerful and innovative works in the field: examples include Patrick Süskind's Das Parfum - Die Geschichte eines Mörders (Perfume - The Story of a Murderer, 1985), East German author Jurek Becker's Bronsteins Kinder (Bronstein's Children, 1986) and Austrian Nobel Prizewinning novelist Elfriede Jelinek's Gier (Greed, 2000; see Marieke Krajenbrink's analysis in chapter 3 on Austrian crime).

At first glance there may be few contemporary subgenres - such as the Regionalkrimi (regional crime novel) or the Öko-Krimi (ecological crime novel highlighting environmental concerns) - that appear to be home-grown, but as this volume will show, German-language crime writers have taken narrative forms from British, American and European arenas and made them their own, refining and extending them in the context of their individual cultures and national concerns. For example, many German-language crime narratives draw on long-standing traditions of political satire in magazines, cabaret and literature, resulting in blackly humorous critiques of past and present society (see chapters 3, 6 and 7 on Austrian, women's and historical crime). This is a process of acculturation in its complex, modern sense. As Eva Kushner and Milan Dimic argue,

[i]n the past, acculturation has often manifested itself through the dominance of an invading or invasive culture over another... Yet, it can be shown that the receptor culture, far from being passive, has the ability to appropriate and transform the 
invader culture which in turn undergoes acculturation, a dynamic of great complexity, never at a standstill. ${ }^{23}$

Here, then, acculturation is figured as a vibrant cross-fertilization that leads to innovation on the part of the receptor culture rather than simply reproducing existing cultural forms. However, it should be emphasized that German-language crime fiction has also been shaped by its own crime-writing heritage, for in the case of the early detective story, it was German-speaking crime writers who led the way.

The pioneers (1828-1933)

Scholars begin the history of German-language crime fiction in different places. Some, like Winfried Freund, view early works by major writers as origin texts: Friedrich Schiller's Kriminalbericht (crime report) Der Verbrecher aus verlorener Ehre (The Criminal of Lost Honour, 1786), which is based on a genuine case, Heinrich von Kleist's Der Zweikampf (The Duel, 1811) and E. T. A. Hoffmann's Das Fräulein von Scudéri (Mademoiselle de Scudéri, 1819), set in France during the reign of Louis XIV. ${ }^{24}$ However, as Ailsa Wallace argues, 'concentrating on the canonical "greats" of German literature', perhaps in order 'to invoke respectability for the German tradition of crime writing', can result in overlooking the works of less famous authors who are the true innovators in the field..$^{25}$ By contrast, Hans-Otto Hügel's groundbreaking 1978 study of nineteenth-century German detective stories excavates an arguably more detailed and precise history of popular German crime, and it is this developmental arc that Mary Tannert foregrounds in chapter 2 of the volume. ${ }^{26}$

Tannert explores the emergence of German-language crime fiction in the context of its relatively early maturity: Adolph Müllner's Der Kaliber (The Caliber, 1828), the first German-language detective story, was published a full thirteen years before the text usually regarded as the model for the genre, Edgar Allan Poe's The Murders in the Rue Morgue (1841). She shows how Müllner, Otto Ludwig and other nineteenth-century authors from German-speaking Europe were crimewriting pioneers: influenced by Romanticism, the Enlightenment and manifold legal advances in the German-speaking world, they developed the detective story ahead of both America and Britain. A complementary exploration of another key text, Annette von Droste-Hülshoff's Poetic Realist novella Die Judenbuche (The Jew's Beech, 1842), is provided by Faye Stewart in chapter 6 on the Frauenkrimi.

Tannert goes on to analyse 1870s crime narratives by J. D. H. Temme and Adolf Streckfuss, which feature public servants as investigators, as well as the influence of Conan Doyle's Holmes on Balduin Groller's Austrian Dagobert novellas (1910 1912), and the prolific work of pioneering female crime authors such as Auguste Groner (also Austrian), Luise Westkirch and Eufemia von Adlersfeld-Ballestrem between 1890 and 1936. In addition, Martin Rosenstock's discussion of early 
Swiss crime fiction in chapter 4 shows how the French eighteenth-century Pitaval (encyclopedic volumes about notorious criminal cases, 1734-43) stimulated the interest of the bourgeois European reading public in criminality, and analyses two important texts: Temme's Der Studentenmord in Zurich (The Murder of a Zurich Student, 1872) and Carl Albert Loosli’s Die Schattmattbauern (The Farmers of Schattmatt, 1929), which depicts Switzerland on the brink of modernity.

While Conan Doyle's 'Sherlock Holmes' stories (1887-1927) were extremely popular in 1920s and 1930s Germany, along with whodunits by English-language writers such as Christie, S. S. Van Dine, Dorothy L. Sayers and Edgar Wallace, there is also evidence of considerable German-language crime production in this period, shaped by contemporary events and by the modernist movement. The demise of the German empire at the end of the First World War, along with the impact of industrialization and a global economic recession, led to urban life, political unrest and criminality becoming major preoccupations in the Weimar Republic (1919-33) - as illustrated by Alfred Döblin's modernist masterpiece Berlin Alexanderplatz (1929), which relates the experiences of Franz Biberkopf following his release from prison. In addition, the stories of German serial killers such as Carl Grossmann (Berlin), Fritz Haarmann (Hannover) and Peter Kürten (Düsseldorf) exerted a fascination over writers, the media and the public, which, as we will see, has endured to the present day.

An eclectic crime series published by Berlin's Verlag Die Schmiede, entitled 'Außenseiter der Gesellschaft: Die Verbrechen der Gegenwart' (Outsiders of Society: Crimes of the Present Day, 1924-5), reflected contemporary concerns through book-length studies on the serial killer Haarmann (by Theodor Lessing), the 1924 Hitler-Ludendorff trial (by Leo Lania) and the case of confidence trickster 'Freiherr von Egloffstein' (by Thomas Schramek). While similar to the Pitaval volumes in their focus on genuine criminal cases, Todd Herzog argues that these texts constitute 'an odd genre that falls between nonfiction (trial reports, criminological treatises) and literary fiction' ${ }^{27}$ As he shows, their 'dossier-like multiperspectival narrative[s]' are notable for countering the dominant, 'single connected [crime] narrative' of Conan Doyle's Holmes stories, thereby refusing easy closure to questions of criminality and calling Enlightenment certainties into question. ${ }^{28}$ Verlag Die Schmiede also posthumously published Franz Kafka's landmark work Der Prozess (The Trial, 1925), which confronts readers with the nightmarish tale of Josef K.'s arrest, trial and punishment for an unspecified crime by a sinister state authority.

A focus on the city, the urban serial killer and the rise of fascism is also visible in Fritz Lang's film $M$ - Eine Stadt sucht einen Mörder ( $M$ - A City Searches for a Murderer, 1931), which features Peter Lorre as the child murderer 'M', loosely based on Peter Kürten. ${ }^{29} \mathrm{~A}$ psychological thriller heavily influenced by expressionism, the film is innovative in its use of sound, parallel editing and the realistic depiction of modern police techniques such as fingerprinting. Its final section shows Berlin's criminals, who have apprehended murderer Hans Beckert ('M'), deciding that he should be executed at a makeshift trial. Horst Lange argues that 
the film, released shortly before the Nazis came to power in 1933, can be read as a warning allegory: crime boss Schränker, presiding as judge in a Gestapo-like leather coat, declares that child murderers should forfeit their legal rights and, using language foreshadowing the Nazis, be 'ausgerottet' (exterminated). ${ }^{30}$ The argument of the lone 'defence lawyer' - that Beckert cannot control his actions due to a psychiatric disorder and should be treated by doctors - is rejected by Schränker and the criminals watching the trial, who are only prevented from lynching Beckert by the arrival of the police. The scene thus illustrates the criminal nature of a future fascist state (murderers visiting arbitrary judgement on the accused) and the ease with which the masses can be manipulated into holding fascist views. However, like the 'Outsiders of Society' series, the film refuses narrative closure. The question of how society should deal with Beckert is left open: the sentence handed down by the state is not disclosed and the film ends with a shot of the grieving mothers exhorting society to take better care of its children. ${ }^{31}$

The key factors that make children vulnerable in $M$ are the size of the city and its criminal elements. A Großstadtkrimi (urban crime novel) examining similar themes to different ends is Erich Kästner's Emil und die Detektive (Emil and the Detectives, 1929). This highly popular children's novel tells the story of Emil Tischbein, who is tasked with delivering 120 Mark to his grandmother in Berlin. Falling victim to a criminal on the train, who gives him drugged chocolate and steals his money, he eventually captures the thief with the help of some Berlin youngsters - his 'detectives'. The criminal threat to children is thus still present (as in $M$ they have a dangerous weakness for sweets), but is overcome by youthful resilience, resourcefulness and teamwork. Unlike the mothers in $M$, Emil's mother need not reproach herself or society at the end of the narrative: her son has proven he can negotiate the dangers of the big city without adult help.

This section closes with two other notable texts. Ich war Jack Mortimer (I was Jack Mortimer, 1933) by Alexander Lernet-Holenia is an Austrian Großstadtkrimi that imports its criminals from the gangster culture of America - albeit with a twist. The crime novel is told from the perspective of Viennese taxi driver Ferdinand Sponer, who picks up American gangster Jack Mortimer only to find that he has been shot dead when they reach their destination. Sponer panics, disposes of the body in the Danube and starts to investigate the crime, while the police, on finding blood in his taxi, make him their prime suspect. The situation is resolved when an American woman confesses to murdering her husband in revenge for his killing of her lover, a certain Jack Mortimer. A relatively sophisticated crime novel for the period with a strong sense of place, the work provides nuanced psychological portraits of the victim and murderers, as well as the hapless Sponer. ${ }^{32}$

Finally, Rahel Sanzara's Das verlorene Kind (The Lost Child, 1926) was a publishing sensation that was critically acclaimed by writers Carl Zuckmayer and Gottfried Benn, translated into eleven languages and awarded the 1926 Kleist Prize. ${ }^{33}$ Possibly based on a nineteenth-century case chronicled in Der neue Pitaval, but tapping into contemporary anxieties about child killers and Lustmord (sex murders), it tells the story of a murderer, his four-year-old victim and her father's 
eventual forgiveness of his crime. Along with Erich Kästner, Sanzara became one of the authors blacklisted by the National Socialists, whose works were destroyed in the Nazi book-burnings of 10 May 1933. ${ }^{34}$ The authorship of crime fiction was not the decisive factor in their ostracism, but rather their political stance or perceived Jewish origin. Ironically, Rahel Sanzara was a stage name: Johanna Bleschke, who selected the pseudonym when embarking on her first career as a dancer and actress, was not actually Jewish at all.

\section{Crime fiction under National Socialism (1933-45)}

As Carsten Würmann shows, crime fiction was published for a mass readership under National Socialism, with 3,000 novels with print runs of over one million appearing between 1933 and $1945 .{ }^{35}$ However, it was only following 1939 that Nazi propaganda officials such as Erich Langenbucher actively sought to shape crime fiction, exhorting crime authors to set their novels in Germany; to present crime realistically, drawing on the model of newspaper reports; to depict the criminal without excusing his behaviour; and, perhaps most importantly, to present German policemen as heroic representatives of the state. ${ }^{36}$ More broadly, crime writers were encouraged to depict Nazi Germany as a modern industrial society with an efficient police force operating in accordance with the rule of law. ${ }^{37}$ Thus, novels like Fred Andreas's Das vollkommene Verbrechen (The Perfect Crime, 1944) emphasize that the Nazi police will always catch the perpetrator, no matter how clever his crime. ${ }^{38}$

Support for the regime was therefore given in a discreet manner by crime fiction, as part of a supposedly apolitical entertainment culture ${ }^{39}$ Hardly any crime novels made specific reference to National Socialism: their narratives were generic, with pronounced similarities to those of the 1920 s and $1950 \mathrm{~s} .{ }^{40}$ Nor were many overtly anti-Semitic. Exceptions include Pieter Coll's three Nagotkin novels (1939), featuring a global Jewish crime organization, and J. Bernitt's Briefe in grauen Umschlägen (Letters in Grey Envelopes, 1944), which depicts a decadent Viennese society of aristocrats, foreigners and rich Jews as a thinly disguised justification for the Nazi annexation of Austria. ${ }^{41}$

However, between 1941 and 1944 the Reichsministerium für Volksaufklärung und Propaganda (Reich Ministry of Public Enlightenment and Propaganda) and the Reichskriminalhauptamt (Reich Principal Criminal Office) worked together with publisher Hermann Hillger to create the 'Neuzeitliche Kriminalromane' (Modern Crime Novels) series, whose works promoted the ideology of the state and can therefore be regarded as National Socialist crime novels. ${ }^{42}$ Hans Rudolf Berndorff's Shiva und die Galgenblume (Shiva and the Gallows Flower, 1943), shows police official Shiva using Sippentafeln (genetic family trees) as an investigative tool to deduce the criminal disposition of an individual. We see Shiva warn Herr van der Haardt against employing a thief due to his family background: he is the son of an alcoholic barkeeper and the grandchild of a prostitute. When 
van der Haardt employs the man, because he thinks social disadvantage drove him to steal, the novel refutes this theory by showing him steal again. The narrative thereby promotes a biological theory of crime that enables Shiva, in his role as an official of the state, to deliver a racial lesson to readers: 'It's the blood. It's the ancestry. The bad blood of the clan. ${ }^{43}$ These sentiments are echoed in the antiSemitic historical drama Jud Süss (The Jew Süss, dir. Veit Harlan, 1940), which details the crimes of Joseph Süss Oppenheimer in eighteenth-century Württemberg. Süss is tried and executed for financial corruption and having sexual intercourse with a Christian woman, after which a decree is passed banning Jews from the state. The film's final words express the hope that German citizens will adhere to this ban to safeguard their children's bloodline. ${ }^{44}$

Würmann argues that the policeman in the 'Neuzeitliche Kriminalromane' series acts 'as a doctor on the body of the people'. ${ }^{45}$ The aim is the excision of deviant or un-German elements from Nazi society, often symbolized, as in Jud Süss, by the execution of the criminal. This type of denouement reflected the reality of the Nazi state: from 1940-3, the number of citizens executed annually rose from 900 to 5,000, with the infamous Volksgerichtshöfe (People's Courts) sentencing 45 per cent of defendants to death between 1934 and $1945 .{ }^{46}$ The function of the death penalty is illustrated in Der Tod fuhr im Zug: Den Akten der Kriminalpolizei nacherzählt (Death Travelled by Train: Told According to the Files of the Criminal Police, 1944), by Axel Alt, the pseudonym of Wilhelm Idhe, a Ministry of Propaganda official. The novel depicts the case of the Berlin S-Bahn strangler, railway worker Paul Ogorzow, a Nazi Party member arrested by the Berlin police in 1941 and executed following a fast-track trial. As Irmtraud Götz von Olenhusen asserts, 'the novel was designed to show not only how effective the powers of law and order were, but also to propagate the ideological line that "degenerate" people must be swiftly exterminated without further consideration" - even if, as in this case, they form part of the Nazi body politic.

A fascinating contrast is provided by Will Berthold's post-war, West German novel Nachts, wenn der Teufel kam: Roman nach Tatsachen (At Night, When the Devil Visited: A Documentary Novel, 1959) on the Bruno Lüdke case. ${ }^{48}$ Lüdke allegedly killed eighty people between 1924 and 1943, and the text shows him being apprehended by Berlin Kriminalkommissar Heinrich Franz in the face of ideologically motivated incompetence: the Nazi authorities deny a serial killer is at work, categorizing the deaths as suicides to keep murder statistics down, and restrict public information about the case, placing citizens at risk. ${ }^{49}$ The Nazi state's criminality is also highlighted when Lüdke targets a Jewish woman, only to find she has been deported: 'This time the murderer . . . arrives too late. Other murderers, paid for by the state, have got there before him. ${ }^{50}$ Later research has cast doubt on Lüdke's guilt, suggesting that he was bullied into giving a false confession by Franz. ${ }^{51}$ Berthold's depiction of Franz as a 'good' Nazi-era policeman is further undermined by Horst Bosetzky's Der Teufel von Köpenick (The Devil of Köpenick, 2009), which depicts Franz using Lüdke to advance his police career. 
The Nazi state's control over literary production via the Ministry of Propaganda, together with an understandable self-censorship on the part of authors, resulted in an almost totally conformist body of crime fiction during the Nazi era. Given its direct engagement with the law, policing and justice, using the crime genre for oppositional purposes carried a high level of risk. Würmann found only one example critical of the system: Adam Kuckhoff and Peter Tarin's Strogany und die Vermissten (Strogany and the Missing Ones, 1941). ${ }^{52}$ This novel adopts a strategy similar to works by other possibly dissenting writers, such as Ernst Junger's Auf den Marmorklippen (On the Marble Cliffs, 1939), encoding its critique in a narrative set in another place and historical moment - in this case, a tsarist Russia populated with corrupt politicians and secret police. In a tragic coda, Kuckhoff was executed in 1943 for his communist opposition to the regime. The only other overt criticism of National Socialism appears to come from outside Germany, in the work of Friedrich Glauser, whose 'Sergeant Studer' series (1936-41) critiques Swiss society, but also shows an acute awareness of larger political developments. As Martin Rosenstock's analysis in chapter 4 shows, Glauser's Matto regiert (In Matto's Realm, 1936) vividly signals the dangers of the Nazi regime.

The vast majority of crime novels written during the Nazi era are thus striking for what they cannot or do not show, namely the criminal actions of the state: the systematic persecution, deportation and murder of Jewish-German citizens and other political, religious, ethnic and sexual minority groups; the appropriation of Jewish businesses and property; and the ideologically determined, extra-judicial actions of the police. As chapter 3 on Austrian crime fiction, chapter 4 on Swiss crime fiction and chapter 7 on historical crime fiction show, it has been left to post-war authors to harness the genre's focus on criminality, guilt and justice to explore National Socialist crimes and to reflect on the legacy of the Nazi past.

\section{Early post-war crime narratives (1945-60) and \\ East German crime fiction (1949-71)}

The earliest post-war Kriminalroman to critique Nazi Socialism is Hans Fallada's Jeder stirbt für sich allein (Alone in Berlin, 1947), which explores the case of Elise and Otto Hampel, executed for treason in 1943 for distributing postcards critical of the regime (see chapter 7). It is one of a group of crime narratives around the time of the Nuremberg War Crime Tribunals (1945-6) that was funded by the Soviet occupiers and sought to lay bare the criminality of the Nazi regime. They include Wolfgang Staudte's film Die Mörder sind unter uns (The Murderers are Among Us, 1946), which was initially entitled Der Mann, den ich töten werde (The Man I will Kill) and showed traumatized ex-soldier Mertens shooting former Nazi commander Brückner, now a successful businessman in spite of his war crimes. This ending was changed by the Soviet authorities to reflect and reinforce the judicial activities at Nuremberg: Mertens is persuaded by Susanne Wallner, a concentration camp survivor, to hand Brückner over to the police so that he 
can be properly tried by the state. Another film, Affaire Blum (The Blum Affair, 1948), an adaptation of Robert Stemmle's 1948 novel, examines the 1926 case of a Jewish-German businessman who was falsely accused of murder by the victim's right-wing German murderer. One of the first texts to explore the origins of National Socialism, it highlights how institutional anti-Semitism predisposed police investigators to believe the murderer's accusations and to prosecute an innocent man.

While some 1950s crime novels engage with the Nazi past, such as Berthold's Nachts, wenn der Teufel kam, others gloss over it. For example, Austrian writer Egon Eis's Duell im Dunkel (Duel in the Dark, 1957) tells of two former soldiers who meet in post-war Hamburg as a policeman and criminal, but studiously avoids mentioning National Socialism. The year 1956 saw the emergence of a West German crime fiction phenomenon representing pure escapism - the 'Jerry Cotton' series, published by the publisher Bastei, which followed the eponymous FBI agent's crime-fighting activities in New York. Served by a collective of over one hundred German-language crime writers, these Heftromane (novels published in booklet form) have been translated into nineteen languages and have a circulation of around 930 million to date. ${ }^{53}$ It is tempting to see the initial success of this series in the 1950s as a reflection of readers' desires for entertainment far removed from West Germany's own social circumstances or its difficult historical past. However, the success of the first West German television crime series, Stahlnetz (1958-68) and its East German counterpart Blaulicht (1959-68), shows that audiences were receptive to crime narratives set on German soil that engaged with local and national concerns (see chapter 8 on the Fernsehkrimi).

The crime-writing luminary of the 1950s was Swiss dramatist and author Friedrich Dürrenmatt, who wrote three novels during this decade: Der Richter und sein Henker (The Judge and His Hangman, 1950), Der Verdacht (Suspicion, 1951) and Das Versprechen: Requiem auf den Kriminalroman (The Pledge: Requiem for the Crime Novel, 1958). Martin Rosenstock analyses these groundbreaking novels in chapter 4 , focusing on the way that metaphysical and philosophical thought influence the characterization of the 'dying detective' in the two Bärlach novels and the 'failed detective' of Das Versprechen - figures who ultimately embody a critique of the Enlightenment tradition. As Kutch and Herzog argue, such 'anti-detective' novels were ahead of their time and illustrate the capacity of German-language crime fiction for innovation. ${ }^{54}$ Dürrenmatt's texts have had a lasting impact within but also beyond the German-speaking world, as Sean Penn's well-received film adaptation, The Pledge (2001), starring Jack Nicholson, Sam Shepherd and Robin Wright, attests.

Crime fiction in the newly formed German Democratic Republic (GDR/East Germany, 1949-90) was shaped by ideological considerations that reflected a rise in Cold War tensions: East German popular fiction was to have a socialist, anti-fascist, political-pedagogical function, and to act as a 'dam' against the tide of popular literature produced by West Germany. ${ }^{55}$ The Amt für Literatur und Verlagswesen (Office for Literature and Publishing Houses), which was established 
in 1951 and subsumed into the Ministerium für Kultur (Ministry of Culture) in 1956, approved publishing licenses and publishers' lists in line with state guidelines, which became increasingly restrictive following the June 1953 workers' uprising and remained stringent until $1961 .^{56}$ Throughout the forty-year lifetime of the GDR, crime fiction, along with all forms of literature, was subject to pendulum swings in state cultural policy, which were tightened or relaxed depending on changes in leadership or larger political events.

Dorothea Germer argues that the first GDR crime novel, Hannes Elmens's Was geschah im D 121? (What happened in D 121?, 1951) is representative of 1950s East German crime fiction in its thematization of class conflict, and its use of a plotline that shows crimes being committed by West German agents or saboteurs and solved by East German citizens or the Volkspolizei (people's police). ${ }^{57}$ This model, which also frequently elides West Germany and fascism, is still visible in the 1960s: the murderer in Gerhard Harkenthal's Rendevous mit dem Tod (A Date with Death, 1962) is a West German former Nazi, who masquerades as an East German citizen while plotting the overthrow of the state. However, the building of the Berlin Wall under East German leader Walter Ulbricht in 1961, which halted significant movement between East and West Germany and reduced Cold War tensions, made this agent/saboteur model increasingly redundant.

In the more culturally relaxed period between 1961 and 1965, East German crime fiction was thought of as a form of high quality popular fiction that could bridge the divide between $U$ - and E-Literatur, leading readers to more serious literary texts. ${ }^{58}$ However, a key problem remained for authors. How to write crime fiction about a communist, classless East Germany in which major crime has been officially eliminated, without also being critical of the state? In 1963, the Hauptverwaltung Verlage und Buchhandel (Central Administration for Publishers and the Book Trade) was established in the GDR's Ministry of Culture and tasked with approving manuscripts and scrutinizing publisher lists. During the politically constrained period that followed between 1965 and 1971, GDR writers such as Gert Prokop and Erich Loest responded to ideological pressures by setting their crime novels outside the GDR, attacking capitalism and linking it to a fascistic West Germany, in what was essentially a reimagining of the old saboteur model. ${ }^{59}$ Thus, Loest's Das Waffenkarussell (The Weapons Carousel, 1968) is set in Nigeria and critiques colonialism, the capitalist trade in illegal weapons and fascism through the depiction of former Nazis fermenting political unrest (see also chapter 5 on the Afrika-Krimi).

The West German Soziokrimi (1960-) and later East German crime fiction (1971-89)

The 1960s and 1970s saw the emergence of the West German Soziokriminalroman or Soziokrimi (social crime novel), also known as the Neue Deutsche Kriminalroman (new German crime novel), whose aim was to explore and critique society. ${ }^{60}$ Two 
sets of influences contributed to this turn in West German crime fiction. The first was political: Chancellor Adenauer's departure from office in 1963 heralded an era in which the 'second generation' - those born after the end of the Second World War - came of age and began to reflect on the actions of their parents under National Socialism. The Eichmann (1961) and Frankfurt Auschwitz trials (1963-5) were extensively reported, with the latter forming the basis for Peter Weiss's play Die Ermittlung (The Investigation, 1965), which used court transcripts to confront audiences with the crimes of the Holocaust and the reluctance of perpetrators to admit guilt or responsibility. ${ }^{61}$ In 1966, the appointment of former Nazi propaganda official Kurt Georg Kiesinger as chancellor was seen as evidence of a flawed West German democracy and politicized many young West Germans. The Ausserparlamentarische Opposition (extra-parliamentary opposition movement) and 1968 student movement campaigned against what they saw as the excessive powers of the CDU/SPD Grand Coalition (1966-9), and for the regulation of the right-wing Springer press. More broadly, influenced by the left-wing analyses of the Frankfurt School, they condemned capitalism and protested against America's involvement in the Vietnam War. The fatal police shooting of student Benno Ohnesorg at a 1967 demonstration was viewed as confirmation of the state's brutal and essentially fascist character. These elements also fed into the emergence of radical left-wing terrorism - the Baader-Meinhof gang or Rote-Armee Frakion (Red Army Faction) in West Germany in the 1970s.

The second factor that encouraged the emergence of the Soziokrimi was literary. In 1962, Richard K. Flesch became editor of Rowohlt's 'rororo thriller' imprint and commissioned the translation of Maj Sjöwall and Per Wahlöö's Swedish ten-part 'Martin Beck' series (1965-75). ${ }^{62}$ In his study on the Soziokrimi, Jürg Brönnimann shows how Sjöwall and Wahlöö turned the crime novel into a vehicle for social criticism, using it to illustrate the negative effects of capitalism on Swedish society. Ending with the near-collapse of Swedish social structures, the series points to the need for an anti-capitalist alternative via the tenth novel's final word - 'Marx', ${ }^{63}$ and proved to be enormously influential on West German crime authors. ${ }^{64}$

Brönnimann argues that Soziokrimi authors such as -ky (Horst Bosetzky), Felix Huby, Hansjörg Martin, Michael Molsner, Irene Rodrian and Fred Werremeier, many of whom were also championed by Rowohlt, were key in transforming ideas about the social function of literature in West Germany. In their view, literary texts were only truly effective when made accessible to a mass audience. ${ }^{65}$ They therefore harnessed the popularity of the crime genre when critiquing West German society, taking care to show a recognizable world that allowed readers to identify with characters, and by extension with certain socio-political positions ${ }^{66}{ }^{\text {Soziokrimi }}$ authors also sought to redefine the notion of crime: 'crime was not to be regarded as an individual act, but rather as a direct, negative consequence of social circumstances' ${ }^{67}$ While the ideas of Frankfurt School thinkers such as Adorno, Habermas and Marcuse were widely discussed at the time, the influence of sociologists such as Emile Durkheim and Robert Merton, who argued that criminal behaviour 
was the product of societal structures and pressures, appears to have been more pronounced on Soziokrimi authors. ${ }^{68}$ Notably, this theorization of crime contrasted sharply with National Socialist ideas of a biologically determined and hereditary criminality.

The writer known as '-ky' was revealed to be sociology professor Horst Bosetzky in 1981. His first crime novel, Einer von uns beiden (One of the Us Two, 1972) is the darkly humorous tale of Berlin sociology professor Dr Rüdiger Kolczyk, who is blackmailed by student Berndt Ziegenhals following his discovery that Kolczyk's doctoral thesis was plagiarized. Neither is a likeable character. Kolczyk is a pompous academic who lectures on working-class history, but is keen to protect his status and affluent lifestyle. Ziegenhals is lazy, with a history of criminal activity, including a spell as a pimp. However, Bosetzky shows how both are at least partially formed by their social backgrounds: the professor falsified his thesis because he needed money for his wife's medical treatment just after the Second World War; the student was orphaned as a result of wartime bombing and placed in a home. Post-war materialism has subsequently shaped their outlooks, and in Ziegenhals's case, led him to take up the role of blackmailer. These insights do not make readers like the characters more, but encourage an understanding of their actions. The text is also careful to refuse judgement: at the end of the narrative, neither character emerges victorious from the duel. Bosetzky went on to write numerous social crime novels set in Berlin and in Bramme, a fictional lower Saxony town with a representative function. As is shown below, the technique of figuring an individual or setting as representative of social types or political/class attitudes is characteristic of the Soziokrimi.

Irene Rodrian was one of the first West German woman crime authors to achieve publishing success and recognition (for further analysis, see chapter 6). Her social crime novel Küsschen für den Totengräber (Kiss for the Gravedigger, 1974), which can also be regarded as an early Frauenkrimi, opens with the attempted murder of unmarried young mother Margot Grimm after giving birth in hospital. Her assailant is the baby's father, Ernst Lorenz, who needs to present the boy as his legitimate offspring in order to secure the family inheritance, a pharmaceutical company. Lorenz uses his wealth as a weapon when trying to gain custody of the baby, paying a porter, senior nurse and Grimm's landlady for information about her movements. Rejected by her bourgeois parents and friends, Grimm is befriended by the Ghanaian Kofi Ocran and finds sanctuary in his student collective. When Lorenz attempts to murder Grimm again, but accidentally kills another person, he is finally caught by the police.

While depicted as rounded individuals, Grimm and Lorenz also represent social types - the disempowered single mother and the amoral capitalist playboy. Lorenz's murderous impulses have their roots in his late father's will, which sets him against his sister in a race to produce a male heir. His descent into madness and eventual suicide figures patriarchal capitalism as an entity that destroys even its own. The narrative ends on a more hopeful note for Grimm: she realizes that her passivity, particularly her silence following the attempt on her life, placed herself and others 
in danger, and develops a more assertive female agency. She applies for a job and moves out of the collective rather than entering into a relationship with Ocran; her professional abilities and a good childcare system will enable her to make an independent life. This ending is radical for the time: being an unmarried mother and choosing to remain so were still largely a social taboo.

Richard Hey's 'Katharina Ledermacher' police procedural series (1973-80) features the first Kommissarin (female police inspector) of German-language crime fiction. The opening novel, Ein Mord am Lietzensee (Murder at Lake Lietzen, 1973), shows the highly capable Ledermacher investigating the murder of an old man. A gang of youths called 'Lucifer's Darlings' is suspected, but Ledermacher establishes that Brückner was actually killed by fellow residents in his old people's home. The novel explores different philosophies of policing, with Ledermacher's boss asserting the guilt of 'Lucifer's Darlings' and advocating the use of force: the novel shows gang members being beaten up by police in a display of state violence. By contrast, Ledermacher's own youth in a children's home helps her to understand how the gang's criminality arises from a combination of social deprivation and a disengagement from society. Her own more risky approach involves engaging gang members in dialogue, which helps her to close the case. The perpetrators turn out to be outwardly respectable older members of society, who have formed what amounts to a geriatric gang. Its leader, Dr Erwin Bockelmann, is a former Nazi judge who uses his legal knowledge to evade justice at the end of the narrative. However, Ledermacher's progressive role within the police force lends Ein Mord am Lietzensee a redemptive quality, and her depiction helps to inspire a new generation of female crime writers. Pieke Biermann may have named her police investigator Karin Lietze in homage to the novel (see also chapter 6) ${ }^{69}$

In Austria during the 1970s, as Marieke Krajenbrink shows in chapter 3, two second-generation writers, Peter Handke and Gerhard Roth, were experimenting with crime fiction in a different way to Soziokrimi authors, by simultaneously employing and subverting genre conventions to problematize the idea of an objective truth in the context of Austrian history and politics. Three first-generation authors should also be mentioned, whose work strongly reflects concerns of the time. The first is the Austrian writer Hans Lebert, whose novel Die Wolfshaut (Wolf's Skin, 1960) draws heavily on the crime genre to expose historical amnesia in relation to the National Socialist past (see chapter 3 for further analysis). The second is Hans Hellmut Kirst, whose satirical crime novels, such as Die Nacht der Generale (The Night of the Generals, 1962), are often set in the Nazi era and figure their murderers as embodiments of a psychopathic, criminal regime (see chapter 7).$^{70}$ Lastly, Nobel Prize winner Heinrich Böll caused significant controversy with his novel Die verlorene Ehre der Katharina Blum oder: Wie Gewalt entstehen und wohin sie führen kann (The Lost Honour of Katharina Blum or: How Violence Comes About and Where It Can Lead, 1974). Adopting Kriminalroman conventions, it tells the story of a woman whose reputation is destroyed by the press following contact with a suspected left-wing terrorist, and subsequently feels driven to murder a journalist. Misinterpreted by some as a legitimization of violence, ${ }^{71}$ the 
text sought to dissect the conditions that make violence possible by critiquing the West German tabloids' commercial exploitation of fears about terrorism, the unconstitutional legal steps to combat extremism (such as the 1972 'Radikalenerlass', a decree prohibiting 'radicals' from taking up public employment) and the criminalization of innocent citizens. Adapted for film in 1975 by directors Volker Schlöndorff and Margarethe von Trotta, with Angela Winkler in the leading role, this powerful novel is viewed as an origin text for later crime novels and thrillers that have engaged with the legacy of Baader-Meinhof terrorism. ${ }^{72}$

On the other side of the Berlin Wall, crime fiction benefitted from a comparatively relaxed cultural policy following Erich Honecker's appointment as East German head of state in 1971 and his pronouncement at the Fourth Conference of the SED Central Committee that socialist literature should not be subject to taboos. ${ }^{73}$ Germer notes that some East German crime fiction now began to engage with criminality within the GDR ${ }^{74}$ a development that dovetailed with the creation of the television crime drama Polizeiruf 110 (Police: Dial 110, 1971-), set in cities such as East Berlin, Rostock and Dresden (see also chapter 8). Crime fiction published in this period can appear surprisingly critical of the regime. Gert Prokop's Einer muss die Leiche sein (Someone has to be the Corpse, 1976) features an SED Party loyalist who murders his mistress after she threatens to derail his political career. Fielitz's confession at the end of the narrative not only reveals the extreme levels of party loyalty needed to rise through the ranks, but also the advantages of being engaged to the daughter of an important party functionary. It is the fear that the engagement will be broken off, thereby terminating opportunities for travel outside the GDR, that leads Fielitz to kill. The novel was published in the wittily named 'DIE' series, established in 1970 by the Verlag Das Neue Berlin. This acronym, which stands for Delikte-Indizien-Ermittlungen (crimesclues-investigations), indicates a shift in attitude: crime novels are viewed less as political-pedagogical tools and more as an accepted form of entertainment perhaps one reason why the denouement of Einer muss die Leiche sein passed through the publication system uncensored.

The expulsion from the GDR of dissident singer-songwriter Wolf Biermann in 1976 signalled the beginning of a more restrictive cultural era. Crime fiction resumed its status as an uncritical literary form and state-sanctioned refuge for writers who were politically out of favour, ${ }^{75}$ as already seen in Erich Loest's case in $1964 .{ }^{76}$ However, it was not possible for the state to completely reverse the advances made during more culturally open times. While ideological restrictions were in place in the 1980s, crime fiction developed a number of diverse functions: as a form of reportage at a time when news coverage told citizens little about the realities of their state, as a means of documenting the problems of everyday life and by extension of GDR society, and as an assertion of the shift from a collective 'ermittelnde Gesellschaft' (investigating society) to a more individual mindset. ${ }^{77}$ Investigators, typically depicted as confident representatives of the state apparatus, might now be shown as uncertain about their methods or the purpose of their work, and perpetrators, previously figured as outsiders or enemies of the state, 
were increasingly depicted as normal GDR citizens who commit murder due to complex social and psychological factors. ${ }^{78}$ Thus, as Germer argues, crime fiction becomes 'an indirect chronicler of the collapse of the GDR' in the final decade of the state's existence. ${ }^{79}$ After the fall of the Berlin Wall in 1989, well-known East German authors such as Jan Eik, Hartmut Mechtel and Ingeburg Siebenstädt (writing as Tom Wittgen; see chapter 6) continued to publish successfully. More recently, the best texts from the 'DIE' series have been republished by Komet, evidencing reader interest in a rebranded, 'cult' East German crime, while contemporary crime authors, such as Simon Urban, have sought to address the legacy of the GDR in their work (see chapter 7 on historical crime fiction).

\section{Turkish-German crime fiction and the Frauenkrimi (1980-)}

The 1980s and 1990s were notable for a number of crime fiction industry developments. In 1984, the Bochumer Krimi Archiv (BKA) was established by West German author and journalist Reinhard Jahn, which in turn set up the annual Deutscher Krimipreis (German Crime Prize) in 1985, judged by a jury of critics, booksellers and academics. 'Das Syndikat - Die Autorengruppe deutschsprachige Kriminalliteratur' (The Syndicate - German-language Crime Fiction Authors' Association), which currently has over 800 members from Austria, Germany and Switzerland, was formed in 1986. It organizes an annual crime convention (Criminale, 1986-) and created the Friedrich-Glauser-Preis (Friedrich Glauser Prize, 1987-), judged by a jury of crime authors. In 1996, the German chapter of the American 'Sisters in Crime' network was established, which became the Mörderische SchwesternVereinigung deutschsprachiger KrimiAutorinnen (Murderous Sisters - Association of German-language Women Crime Authors) in 2007. Each of these organizations aims to promote German-language crime fiction and the interests of Germanlanguage crime authors in rapidly evolving publishing contexts.

The 1980s saw the emergence of a number of Turkish-German crime narratives in West Germany. An important early example is by Aras Ören, a Turkish author who migrated to Germany in 1969: his novel Bitte nix Polizei: Kriminalerzählung (Please No Police: Crime Story) was translated into German and published in 1981. Set in 1973, when Gastarbeiter (foreign guest workers) represented nearly 10 per cent of West Germany's workforce, ${ }^{80}$ its multi-layered narrative can be read as 'a tale of post-war reconstruction on the anvil of Turkish migration' ${ }^{81}$ However, as the novel's subtitle indicates, it is also a story about crime, and is used by the author to highlight the fraught relationship between migrants, West German citizens and the authorities. Its central protagonist, Ali Itir, is unjustly accused of two crimes in the course of the narrative - a sexual assault and an attack on an old man, who subsequently dies. Ali had actually tried to help the man following a winter fall, but fled when the police were called; racist witnesses then misinterpreted his actions as criminal. It is in fact a neighbour, Frau Gramke, who is responsible for the old man's death: she saw him fall, but left him lying 
in the snow as punishment for another crime, a rape he committed thirty years before. The novel ends with the discovery of a body in a canal, which may or may not be Ali. As Tom Cheesman argues, here 'realism gives way to an unobtrusively postmodernist refusal of closure': the reader is left pondering the cause of death (murder/suicide/drowning) and the identity of the corpse. ${ }^{82}$ Ali thus 'becomes an icon not only of the migrant worker as quintessential victim, but also of the migrant worker as quintessentially unknowable subject'. ${ }^{83}$

Four years later, a crime novel appeared that revolutionized depictions of TurkishGermans in West German culture. Written by Jakob Arjouni, a 20-year-old German of non-Turkish heritage, Happy Birthday, Türke! (Happy Birthday, Turk!, 1985) employed a subgenre that had rarely been seen in German-language crime fiction - the hard-boiled, private detective novel - as a vehicle for introducing the first Turkish-German lead investigator, Kemal Kayankaya ${ }^{84}$ Kayankaya is the opposite of Ali Itir: he holds German citizenship, speaks German as his first language, has a state-approved private detective's licence, and asserts himself with wise-cracking confidence when dealing with fellow West Germans and their racist stereotypes. It is difficult to overestimate how groundbreaking this figure was in the 1980s, when public attitudes towards migrants were deteriorating; right-wing arson attacks in the 1990s would claim a number of Turkish lives. Asking German readers to identify with the likeable, football-and-herring-loving Kayankaya directly challenged the dominant image of the Turk as a poorly integrated kebab-shop owner, rubbish collector or criminal, and confronted essentialist notions of German national identity. Drawing on the model of the Soziokrimi, Happy Birthday, Türke! also exposes the corruption of the state and the racism at the heart of West German society. The focus is on German criminality, with the crimes of Turks and other minorities shown in the larger context of unequal social power-relations: a Turkish 'criminal' is shown to have been blackmailed into dealing drugs by corrupt police officers who threatened him with deportation should he not comply. ${ }^{85}$

Crime writer Akif Pirinçci, who migrated to West Germany as a child in 1968, has arguably positioned himself as a writer of popular fiction rather than as a migrant author. ${ }^{86}$ However, as Jim Jordan shows, his eight internationally bestselling Felidae crime novels (1989-2014) featuring Francis the cat detective can be read as allegories of the migrant experience ${ }^{87}$ The first in the series, Felidae (1989), depicts Francis as a marginalized outsider following his arrival in a new neighbourhood, who gains social acceptance by solving a series of cat murders. The third, Cave canem (Cave canem, 1993), explores intergenerational relations, contrasting the migrant and post-migrant attitudes of Francis and his son towards questions of integration and identity. ${ }^{88}$ However, the texts also invite wider, multiple readings: the 'mad scientist' plot in Felidae, which involves the kidnapping of neighbourhood strays for a gruesome programme of experiments, calls the ethics of animal experimentation into question, but in a specifically German context also evokes memories of Nazi medical experimentation in concentration camps. One of the scientist's victims later attempts to create a pure race of undomesticated cats to subjugate the human race, but is stopped by Francis, who 'rejects the 
replacement of one form of tyranny with another, accepts the desirability of interbreeding, and argues for a future vision of a society in which all animals (including humans) are equal' ${ }^{89}$

New millennium Turkish-German works include Feridun Zaigmoglu's Leinwand (Canvas, 2003), a parody of a hard-boiled police detective novel. Leinwand is Zaigmoglu's only foray into crime fiction, and shows Kiel police detective Seyfeddin Karasu investigating the torching of a homeless man and the drowning of a woman from eastern Germany. However, Zaigmoglu subverts the genre by showing one of the cases being solved without Karasu and by killing him in a car-bomb explosion before he can solve the second. The first Turkish-German police inspector in German-language history thus has a regrettably short career.

More recently, Su Turhan's 'Kommissar Pascha' series (2013-) shows TurkishGerman police inspector Zeki Demirbilek investigating migrant/racist crimes as the head of Munich's Sonderdezernat Migra (Special Migration Unit). Demirbilek is a highly integrated Turkish migrant, who moved to Germany aged twelve and has enjoyed a successful career in the German police. His identity is an almost perfect blend of German and Turkish: he views Munich and Istanbul as his home cities, speaks German and Turkish fluently, supports Bayern and Fenerbahçe football clubs, and observes Ramadan, but drinks alcohol and eats pork. He holds a German passport, but would have preferred dual TurkishGerman citizenship (not allowed under German law at that point). Demirbilek thus differs substantially from Arjouni's Kayankaya, an insider-outsider figure operating beyond police structures who speaks no Turkish, and from Tatort's Cenk Batu, a Hamburg policeman who works in an undercover capacity and speaks little Turkish (see chapter 8 on the Fernsehkrimi for analysis of this figure).

Demirbilek can be regarded as an overly idealized Turkish-German character, whose attachment to traditional Turkish barbers and delicacies makes him interesting to German readers without being threatening: he is the 'civilized' Turkish German who allows the vision of an integrated society to seem achievable. However, his depiction can also be applauded for normalizing the idea of a senior TurkishGerman police officer respected for his experience, integrity and expertise. In addition, his integration into German society - rather than complete assimilation - asserts the right of Turkish Germans to retain a strong sense of Turkish identity, rather than having to face the 'entweder-oder' (either-or) of German citizenship law. Demirbilek has successfully become German but has also remained Turkish, and this dual identity is shown to enrich both German policing and society.

As this survey chapter has already illustrated, women writers such as Annette von Droste-Hülshoff, Auguste Groner, Luise Westkirch, Eufemia von AdlersfeldBallestrem, Rahel Sanzara and Irene Rodrian contributed significantly to Germanlanguage crime fiction between the 1840s and 1970s with a number of rich and complex texts. Scholars like Ailsa Wallace continue to rediscover women crime writers, such as Hermynia Zur Mühlen, who, while best known for her anti-fascist exile literature, also wrote six crime novels in the 1920s under the name of Lawrence H. Desberry, featuring socialist reporter-detective Brian O'Keefe. ${ }^{90}$ Like Groner 
and Sanzara, Zur Mühlen was extremely successful in her lifetime. The O'Keefe novels were serialized in newspapers, published in multiple editions and translated, but then, like Groner's and Sanzara's works, they largely disappeared from literary histories that privileged high culture and the output of male authors. ${ }^{91}$

In chapter 6, Faye Stewart places the work of women crime writers centre stage, exploring how the Frauenkrimi (women's crime novel) flourished in the 1980s, partly due to the legacy of the 1968 student movement and partly due to the influence of Anglo-American feminist crime writers such as Sara Paretsky, Val McDermid and Sue Grafton. Written by, about and for women, the Frauenkrimi contested inequality through the agency of its female sleuths, celebrated new constructions of sexuality and queerness, and cast a critical eye on patriarchal society. As Brigitte Frizzoni argues, gender hierarchies of the 1980s and 1990s were thoroughly subverted by the increased presence in crime narratives of the 'Kommissarin, Forensikerin, Privatermittlern, Amateurin, Täterin oder Rächerin' (female police inspector, female forensics expert, female private investigator, female amateur detective, female perpetrator or female avenger). ${ }^{92}$ Stewart's wide-ranging chapter explores the work of pioneering female crime writers in the 1950s and 1960s such as Irene Rodrian and Ingeburg Siebenstädt (the 'Agatha Christie of the GDR'), and the literary, publishing and critical contexts in which the Frauenkrimi emerged. She goes on to examine the socio-political issues addressed by seminal German and Austrian feminist authors such as Pieke Biermann, Doris Gercke, Christine Grän and Ingrid Noll - from women's rights and gay rights to the expansion of the European Union. Chapter 3 by Marieke Krajenbrink provides additional discussion of Austrian women crime writers such as Elfriede Jelinek, as does chapter 8 on the depiction of female investigators in the Fernsehkrimi.

This section ends with a genre outlier: Patrick Süskind's extraordinary literaryhistorical crime narrative Das Parfum - Die Geschichte eines Mörders (PerfumeThe Story of a Murderer, 1985), which enjoyed enormous international success and was adapted for film by German director Tom Tykwer in 2006. Set in eighteenthcentury France, the narrative is told in the first person by perfumer Jean-Baptiste Grenouille, whose astonishing sense of smell leads him to kill young virgins in an obsessive quest to distil the perfect scent. A novel about the relationship of the senses, desire and morality, it has sold over 15 million copies, been translated into numerous languages and remains an outstanding example of twentiethcentury German literature.

\section{Historical crime fiction, regional crime fiction and the rise of the Afrika-Krimi (1989-)}

A diverse range of German-language crime fiction has been produced since the fall of the Berlin Wall in 1989. As Katharina Hall shows in chapter 7, the intensive re-examination of Germany's twentieth-century history following German 
reunification has led to a boom in historical crime fiction. Key examples include Christian von Ditfurth's 'Stachelmann' series (2002-), which uses a historiandetective to examine the Nazi past, Andreas Pittler's 'Bronstein' series (2008-), which explores Austrian history between 1913 and 1955, Ferdinand von Schirach's Der Fall Collini (The Collini Case, 2010), which examines the failure of post-war justice in relation to Nazi crimes, and Simon Urban's Plan D (Plan D, 2011), an alternative history of the GDR that implicitly critiques post-reunification Germany. In chapter 3, Marieke Krajenbrink also provides analysis of a number of Austrian crime novels that engage with the fascist past and its legacies, such as Wolf Haas's Auferstehung der Toten (Resurrection, 1996) and Paulus Hochgatterer's Die Süße des Lebens (The Sweetness of Life, 2006), which probe the disjunction between idyllic tourist images and the more complex reality beneath, thereby subverting the Heimatroman (homeland novel) tradition and its problematic associations.

The 1990s saw the Regionalkrimi, Regiokrimi or Heimatkrimi (regional crime novel) become increasingly popular. As Sascha Gerhards argues, this subgenre complements the emphasis of historical crime novels on the 'vertical' axis of the past through a 'geographical, horizontal mapping' of provincial and rural spaces, dialects and cultures. ${ }^{93}$ Its origins are to be found in the strongly regional character of the Heiliges Römisches Reich (Holy Roman Empire of the German Nation; 800-1806), whose echo persists in the federal Länder (states) of modern Germany, and in the German fascination with landscape, evidenced in the work of Romantic artists such as Caspar David Friedrich (1774-1840), which depicts nature for allegorical ends, but also celebrates specific regional spaces, such as Greifswald or the island of Rügen. Droste-Hülshoff's Die Judenbuche (1842), set in the Westphalian mountains, could well be viewed as a regional crime narrative, as could the television crime series Tatort (1970-), which features investigative teams in different cities and regions (see also chapter 8). Ralf Koss argues that while Tatort and crime novels such as Jürgen Lodemann's Anita Drögemöller und die Ruhe an der Ruhr (Anita Drögemöller and the Peaceful Ruhr, 1975) were targeted at an 'überregionales Publikum' (an audience beyond the region in question), the 'new regional crime novel' of the 1990s was hyperlocal, placing such emphasis on topographical detail and dialect that 'crime novels from Cologne [held] barely any attraction for crime fans from Munich' ${ }^{94}$ Christine Lehmann notes in 2008 that the popularity of Regionalkrimis has led publishers to specialize in the subgenre and specific regions, such as Grafit Verlag (Dortmund), Emons Verlag (Cologne) and Gmeiner Verlag (Meßkirch). ${ }^{95}$ She concedes that local detail can take precedence over quality, with the Regionalkrimi often reviewed as a local event rather than as a literary text. ${ }^{96}$ Too cosy to be 'gesellschaftskritisch' (critical of society), ${ }^{97}$ the Regionalkrimi 'becomes, in a best case scenario, part of a native folklore, and in the worst, relapses into provincialism' ${ }^{98}$

However, many crime authors have challenged negative perceptions of regional crime fiction by combining local settings - arguably no different to that of smalltown Ystad in Henning Mankell's best-selling Swedish 'Wallander' series with crime narratives that examine larger issues, such as Rainer Gross's Baden- 
Württemburg Krimis, which engage with the legacy of Nazi euthanasia. ${ }^{99}$ Other examples include Jacques Berndorf's 'Siggi Baumeister/Eifel Krimi' series (1989-), set in the Eifel region in western Germany; Wolf Haas's 'Simon Brenner' private detective series (1996-2009), located in Salzburg (see chapter 3); and Nele Neuhaus's 'Bodenstein and Kirchhoff' police procedural series (2006-), set in the Taunus region of western Germany. Volker Klüpfel and Michael Kobr's highly successful Allgäukrimis, which feature Inspector Kluftinger and are located in the southern German region of Allgäu in Swabia, have sold 750,000 novels since 2003 and resulted in a television adaptation. They demonstrate how a regional crime series can become a national success and disprove Koss's view that regional crime authors target a narrow audience. ${ }^{100}$ Rather, as Kutch and Herzog argue, their 'hyperlocal customs, locations and speech patterns combine with global concerns to form a potent mix that locates these novels both specifically and globally'. ${ }^{101}$

As Julia Augart shows in chapter 5, the subgenre of the Afrika-Krimi-Germanlanguage crime novels set in Africa or with African characters and themes - also grew significantly in the 1990s, due to rising interest in literary representations of Africa and increased discussion of postcolonial issues. While crime novels set in Africa have existed since the golden age of crime, the first German Afrika-Krimi was Henry Kolarz's Kalahari (1977), set in Zimbabwe, Botswana and South Africa. Nearly one hundred other examples have been published since then, especially since the beginning of the new millennium. Augart discusses the Afrika-Krimi in the context of the contemporary German Africa novel and African crime fiction, but also in relation to historical and regional crime fiction from the Germanspeaking world. Through comparative analysis, she explores how German, Austrian and Swiss authors deploy African settings, address a range of topics and themes, and critique the West's past and present relations with Africa. The chapter also includes analysis of Bernhard Jaumann's Namibia crime novels, with a particular focus on Steinland (Stoneland, 2012), the second in the 'Clemencia Garises' series, which explores the complex legacy of Germany's colonial past in Deutsch-SüdwestAfrika (German South West Africa), as Namibia was termed between 1884 and 1915.

\section{Crime fiction of the new millennium and the lacuna of Jewish-German crime fiction}

Present-day German-language crime fiction is vibrant and diverse. In the past, it has occupied the position of poor relation to English-language crime fiction in the German book market: as late as 2008 , only one-third of crime novels published in Germany were by home-grown authors (180-200 compared to around 600 translated foreign works). ${ }^{102}$ However, today bookshops showcase a mixture of German-language and international crime fiction, and best-sellers are often German, suggesting that a more equal balance is evolving. These texts may 
celebrate a German-speaking or specifically regional culture, such as Klüpfel and Kobr's Allgäukrimis; shine a spotlight on the police treatment of ethnic minorities, like Franz Dobler's Ein Bulle im Zug (Cop on the Train, 2014); address issues such as globalization and the power of the pharmaceutical industry, like Wolfgang Schorlau's Der letzte Flucht (The Last Escape, 2011); explore crossborder criminality in the context of European expansion, like Maria Gronau's Weiberschläue (Women's Shrewdness, 2003), or fruitfully exploit Anglo-American commercial models, like Frank Schätzing's apocalyptic thriller, Der Schwarm (The Swarm, 2004). As Martin Rosenstock shows in chapter 4, Swiss crime fiction has also found worthy successors to Glauser and Dürrenmatt in recent years, with Hansjörg Schneider's 'Hunkeler' series and Urs Schaub's 'Tanner' series drawing adeptly on their crime fiction heritage, while reinvigorating modern Swiss crime writing through their social critique and international outlook.

German-language crime fiction is now also increasingly seen in English translation, thanks in part to the promotional activities of the Goethe-Institut and New Books in German. ${ }^{103}$ Long-translated authors include Jakob Arjouni, Pieke Biermann, Friedrich Dürrenmatt, Friedrich Glauser, Petra Hammesfahr, Ingrid Noll and Patrick Süskind. More recently a new wave of contemporary Germanlanguage crime fiction has been translated into English by Anthea Bell, Jamie Bulloch and Katy Derbyshire, and published by MacLehose, Orion, Pan, Penguin, Simon \& Schuster, Weidenfeld \& Nicolson, Quercus, Vintage and Serpent's Tail. These texts draw on diverse subgenres and national crime-writing traditions, and include Bernhard Aichner's revenge thriller Totenfrau (Woman of the Dead, 2014; see chapter 3), Sascha Arango's Patricia Highsmith homage Die Wahrheit und andere Lügen (The Truth and Other Lies, 2014), Jan Costin Wagner's Finnish 'Joentaa' police procedural series, which draws on Scandinavian noir, Sebastian Fitzek's disturbing psychological thrillers, Hochgatterer's Die Süße des Lebens (see chapter 3), Bernhard Jaumann's Die Stunde des Schakals (The Hour of the Jackal, 2010; see chapter 5), Elfriede Jelinek's Gier (see chapter 3), Neuhaus's 'Bodenstein and Kirchhoff' police procedural series, von Schirach's courtroom drama Der Fall Collini (see chapter 7), Andrea Maria Schenkel's Tannöd (The Murder Farm, 2006; see chapter 7) and Urban's Plan D (see chapter 7). Young German writers with Eastern European heritage, such as Alina Bronsky, whose novel Scherbenpark (Broken Glass Park, 2008) explores a teenage Russian migrant's experiences following the murder of her mother, and Croatian-born Zoran Drvenkar, whose hard-hitting thriller Sorry (Sorry, 2009) won the 2010 Friedrich Glauser Prize, have also attracted international interest and praise.

The traditional distinctions between high and low culture noted at the beginning of this chapter have also become less rigid over time. Journalist and critic Tobias Gohlis has contributed significantly to the increased cultural appreciation of crime fiction in Germany through his establishment in 2001 of a crime-writing column in the broadsheet Die Zeit, along with the online KrimiZEIT-Bestenliste (monthly crime fiction highlights). In common with English-language authors, German-language crime writers are also consciously creating and promoting 
hybrid texts that fuse 'literary' and 'popular' fiction, extracting what they regard to be the best of both genres. As Simon Urban, interviewed about the influence of Michael Chabon's work on his own, comments:

what fascinated me was precisely this unbelievably rare mixture: an aesthetic concept, which logically suggests E-Literatur [serious literature], combined with an original crime fiction concept, the best of U-Literatur [popular fiction]. When this kind of combination succeeds, then in principle we are talking about a new genre, EU-Literatur [serious popular fiction]. ${ }^{104}$

Such hybridity has of course long been visible in works by Austrian, German and Swiss writers such as Jelinek, Fallada and Dürrenmatt, but the confidence with which younger writers are embracing and challenging the conventions of crime fiction promises the continued emergence of high-quality German-language texts that address complex political, social and historical questions, while successfully reaching mass audiences through this enduringly popular literary form.

This chapter closes with an acknowledgement of an absence. When surveying German-language crime fiction of the twentieth century, there is a lack of readily identifiable texts by Jewish-German, Jewish-Austrian or Jewish-Swiss authors, particularly in contrast to the numerous works by Jewish crime writers in the English-speaking world, such as Harry Kemelman's 'Rabbi Small' series (1964-96), Faye Kellerman's 'Decker and Lazarus' series (1986-), Michael Chabon's The Yiddish Policeman's Union (2007) and many more. ${ }^{105}$ The reasons for this absence could be numerous. Most obviously, the mass migration and mass murder of Jewish citizens under National Socialism had a devastating, long-term effect on Jewish culture in Europe. However, the question of whether there has ever been a tradition of crime writing by Jewish authors in the German-speaking world remains largely unexplored. It may be that there are only a small number of such texts; alternatively, Jewish German-language crime novels may exist, but have yet to be properly unearthed or researched. A recent German encyclopedia that surveys Juden und Judentum im Detektivroman (Jews and Jewishness in the Detective Novel), but contains neither entries for Jewish German-language crime novels nor a recognition of this absence in its introduction, suggests that a further academic focus on this area is required. ${ }^{106}$

Research for this volume has not identified any contemporary Jewish Germanlanguage crime authors who have produced significant numbers of texts, although the possibility that some exist but do not identify themselves publicly as Jewish cannot be excluded. However, a number of post-war Jewish German-language texts draw on the conventions of crime fiction, especially when writing about National Socialist crimes. One example is Edgar Hilsenrath's controversial novel Der Nazi und der Friseur (The Nazi and the Barber), which was first published in translation by Doubleday in 1971 and by German publisher Helmut Braun in 1977. This highly satirical Kriminalroman is narrated by Max Schulz, a Nazi SSperpetrator, who steals the identity of Jewish concentration camp victim Itzig 
Finkelstein to escape persecution for his war crimes. Schulz's post-war story becomes increasingly grotesque: not only does he emigrate to Israel as a Holocaust survivor, complete with circumcision and fake Auschwitz prisoner number, he also confesses his crimes to a retired West German magistrate in 1967, who refuses to take him seriously. Thus, even when Nazi war criminals freely admit their crimes, the West German legal system is shown turning a blind eye.

In Austrian contexts, Albert Drach's Untersuchung an Mädeln. Kriminalprotokoll (Investigating the Girls. Criminal Report, 1971) critiques sexism and social prejudice through the depiction of a court case in which two young women are accused of murdering a man who raped them while they were hitchhiking, even though his body has never been found. Doron Rabinovici's Suche nach M. (The Search for $M, 1997)$, makes use of crime genre elements in its depiction of two secondgeneration children of Holocaust survivors who are psychologically scarred by their parents' experiences: Dani Morgenthau has a compulsive desire to claim guilt for crimes he did not commit, while Arieh Scheinowitz works for the Israel Secret Service, identifying 'enemy targets' for the assassin's bullet. Notable, too, is the novel Bronsteins Kinder (Bronstein's Children, 1986), by East/West German author Jurek Becker, set in a 1973 GDR, which shows teenager Hans Bronstein discovering that his Holocaust-survivor father has kidnapped a former concentration camp guard. Hans is presented with a moral quandary - whether to let the man go or to allow his father to exact extra-judicial justice for past crimes.

The most mainstream recent crime novel by a Jewish-German author is J. Monika Walther's Goldbroiler oder die Beschreibung einer Schlacht: Kriminalgeschichte (Roast Chicken or the Chronicle of a Slaughter: Crime Story, 2009). Set shortly after the fall of the Berlin Wall in Warnemünde, it shows former East German citizens floundering economically in the new order. The villains are former Nazis from the west, who co-opt eastern neo-Nazis, former Stasi members and disgruntled former GDR citizens into activities such as extortion, smuggling and importing women as sex workers from Eastern Europe. While overloaded, the narrative provides an interesting depiction of how essentially good people, such as private eye Ida Waschinski, can be corrupted due to financial pressures. Although some villains are shown receiving Old Testament-style justice (they are shot with a gun from Buchenwald concentration camp), the novel's ending is bleak: the law is shown to be fundamentally corrupt, and the most powerful villains maintain their power.

Two other interlinked crime fiction developments are worth noting. The first is the use of Jewish-German figures in crime fiction by Turkish-German writers. Hilal Sezgin's Der Tod des Maßschneiders (Death of a Tailor, 1999), set in Frankfurt in 1885, follows a young Jewish-German woman investigating an apparently anti-Semitic murder and has been called 'an important debut that implicitly and sensitively poses in a new way the question about a Turkish and Jewish "shared fate" in Germany'. ${ }^{107}$ More recently, Esmahan Aykol's Hotel Bosporus (Hotel Bosphorus, 2004) introduces readers to Kati Hirschel, a German with Jewish heritage, who owns a crime bookshop in Istanbul and investigates cases with 
Turkish police inspector Batuhan Önal. Secondly, the Jewish voice in Germanlanguage crime fiction is increasingly represented by non-Jewish writers, a proxy that may be viewed as problematic in certain contexts. For example, the main protagonist of Harald Gilbers's recent crime novel Germania (2013), which is set in 1944 Nazi Germany, is Jewish former police inspector Richard Oppenheimer, who is ordered to help the SS to solve a serial killer case. Neither the historical (im)plausibility of such a scenario nor the issue of a third-generation German author writing from the perspective of a Jewish person living under Nazism has been addressed by German reviewers. Lastly, Katharina Höftmann, a young German writer living in Israel, has broken new ground in her 'Assaf Rosenthal' series (2012-). The opening novel, Die letzte Sünde (The Final Sin, 2012), introduces readers to Tel Aviv police detective Rosenthal, a former army officer who worked in the occupied territories. He is depicted as a committed Zionist who, in spite of discussions with a more liberal colleague, holds hard-line views on the Palestinian conflict. It will be interesting to see if Rosenthal's attitudes are challenged in future investigations of the series. A far more welcome development, however, would be to see the history, society and culture of the German-speaking world refracted through the gaze of a new wave of Jewish crime writers from Austria, Germany and Switzerland.

\section{Notes}

1 'Ohne Zweifel trägt der Kriminalroman alle Merkmale eines blühenden Literaturzweiges zur Schau.' Bertolt Brecht, 'Über die Popularität des Kriminalromans (1939-40)', in Jochen Vogt (ed.), Der Kriminalroman: Poetik - Theorie - Geschichte (2nd edn; Munich: Fink Verlag, 1998), pp. 33-7 (p. 33). My translation.

2 For example, Jan Costin Wagner's Das Schweigen (Silence) is available in translation, but Richard Hey's Ein Mord am Lietzensee (Murder at Lake Lietzen), is not as yet.

3 This lack of academic engagement is explored in Volker Neuhaus, " $\mathrm{Zu}$ alt, um nur zu spielen": Die Schwierigkeiten der Deutschen mit dem Kriminalroman', in Sandro M. Moraldo (ed.), Mord als kreativer Prozess: Zum Kriminalroman der Gegenwart in Deutschland, Österreich und der Schweiz (Heidelberg: Universitätsverlag Winter, 2005), pp. 9-19.

4 'Unterhaltungsliteratur' and 'Ernstliteratur'.

${ }^{5}$ See Nicola Barfoot, Frauenkrimilpolar féminin: Generic Expectations and the Reception of Recent French and German Crime Novels by Women (Frankfurt a. M.: Peter Lang, 2007), pp. 61-2.

${ }^{6}$ See Jochen Vogt's seminal 1971 edition of Der Kriminalroman, which also contains essays on crime fiction by Walter Benjamin, Bertolt Brecht and Siegfried Kracauer. Jochen Vogt (ed.), Der Kriminalroman - Zur Theorie und Geschichte einer Gattung (Munich: Wilhelm Fink Verlag, 1971), 2 vols.

7 Studies often only analyse German-language authors in sections on post-1960s crime fiction. Neuhaus singles out Hans-Otto Hügel's study Untersuchungsrichter, Diebsfänger, Detektive: Theorie und Geschichte der deutschen Detektiverzählung im 19. Jahrhundert (Stuttgart: J. B. Metzler, 1978) as an exception to this rule. Neuhaus, “'Zu alt, um nur zu spielen", p. 11. 
8 As late as 1997, Alf Meyer-Ebeling claimed that crime novels were banned in Nazi Germany. See Carsten Würmann, 'Zum Kriminalroman im Nationalsozialismus', in Bruno Franceschini and Carsten Würmann (eds), Verbrechen als Passion. Neue Untersuchungen zum Kriminalgenre (Berlin: Weidler, 2004), pp. 143-86 (p. 180).

9 'Die deutschsprachige Kriminalliteratur hat keine Tradition? Stimmt, aber sie könnte eine haben.' Advert for Criminalbibliothek (crime library) 1850-1933 in Michael Molsner, Rote Messe (Cologne: Edition Köln, 2008), p. 238. 'Edition Köln - der Verlag der (Krimi-) Geschichte schreibt.' Advert for Kriminelle Sittengeschichte Deutschlands (German History of Criminal Vices) 1957-1993, in Emilie Heinrichs, Leibrenten (Cologne: Edition Köln, 2008), p. 412.

${ }^{10}$ Ulrike Götting is one of the first to explore 'crime fiction in German' in her study Der deutsche Kriminalroman zwischen 1945 und 1970: Formen und Tendenzen (Wetzlar: Kletsmeier, 1998), which examines West German, East German, Austrian and Swiss crime

${ }^{11}$ Current population statistics are as follows: Germany, 80 million; Austria, 8.5 million; Switzerland, 8 million. The population of East Germany was 16 million in 1989. According to Almuth Heuner, Austria contributes 5 per cent and German-speaking Switzerland 3 per cent of all authors, books, publishers and readers to the Germanlanguage book market. Cited in Barry Forshaw, Euro Noir: The Pocket Essential Guide to European Crime Fiction, Film and TV (Harpenden: Pocket Essentials, 2014), p. 85.

12 This volume views the German-speaking world as Germany, Austria, Switzerland and the former East Germany, and discusses former German colonies in Africa, such as Namibia. However, other countries where German is an official language, such as Liechtenstein, Belgium, Luxembourg and the province of South Tyrol (Italy), could equally be included.

13 'Der Kriminalroman erzählt die Geschichte eines Verbrechens, der Detektivroman die Geschichte der Aufklärung eines Verbrechens.' Richard Alewyn, 'Anatomie des Detektivromans', in Vogt (ed.), Der Kriminalroman, pp. 52-72 (p. 53).

14 'Die Kriminalgeschichte macht den Leser zuerst mit dem Täter, dann mit der Tat, zuletzt mit den Folgen der Tat bekannt; sie interessiert sich für die seelischen Vorgänge, die zu der Tat geführt haben . . . Umgekehrt die Detektivgeschichte. Sie beginnt mit dem Auffinden der Leiche, rekonstruiert die Tat aus Indizien und kommt am Ende dem Verbrecher auf die Spur; ihr Interesse gilt der geistigen Arbeit des Detektivs, so daß die Motive des Täters nur als Indizien oder zur Sicherung des juristischen Tatbestands in Betracht kommen.' Heinrich Henel, 'Der Indizienstil und die Haltung des Lesers', in Annette von Droste-Hülshoff, Die Judenbuche. Mit Materialien, ed. Helmuth Widhammer (Stuttgart: Klett, 1979), pp. 82-8 (p. 86).

15 See, for example, Peter Nusser, Der Kriminalroman (3rd edn; Stuttgart: J. B. Metzler, 2003 [1980]), pp. 80-106.

16 Nusser, Der Kriminalroman, pp. 93-8.

17 Jürg Brönnimann, Der Soziokriminalroman: ein neues Genre oder ein soziologisches Experiment? Eine Untersuchung des Soziokriminalromans anhand der Werke des schwedischen Autoren Sjöwall and Wahlöö und des deutschen Autors - ky (Wupperthal: NordPark, 2004).

18 Tom Zwaenepoel, Dem guten Wahrheitsfinder auf dem Spur: Das populäre Krimigenre in der Literatur und im ZDF-Fernsehen (Würzburg: Könighausen und Neumann, 2004), p. 35 .

19 Barfoot, Frauenkrimi/polar féminin, pp. 9-13. 
20 Zwaenepoel, Dem guten Wahrheitsfinder auf dem Spur, p. 114.

${ }^{21}$ Arlene Teraoka, 'Detecting Ethnicity: Jakob Arjouni and the Case of the Missing German Detective Novel', The German Quarterly, 72/3 (1999), 265-89.

${ }^{22}$ Barbara Korte and Sylvia Paletschek, 'Geschichte und Kriminalgeschichte(n): Texte, Kontexte, Zugänge', in Barbara Korte and Sylvia Paletschek (eds), Geschichte im Krimi: Beitrage aus den Kulturwissenschaften (Cologne/Weimar/Vienna: Böhlau, 2009), pp. 7-28.

23 Eva Kushner and Milan V. Dimic, 'Introduction', in Eva Kushner and Milan V. Dimic (eds), Acculturation (Berlin: Peter Lang, 1994), pp. 1-3 (p. 3).

24 Winfried Freund, Die deutsche Kriminalnovelle von Schiller bis Hauptmann. Einzelanalysen unter sozialgeschichtlichen und didaktischen Aspekten (Paderborn: Schöningh, 1975).

25 Ailsa Wallace, 'Murder in the Weimar Republic: Prejudice, Politics and the Popular in the Socialist Crime Fiction of Hermynia Zur Mühlen', in Bruce B. Campbell, Alison Guenther-Pal and Vibeke Rützou Petersen (eds), Detectives, Dystopias and Poplit: Studies in Modern Genre Fiction (New York: Camden House, 2014), pp. 91-116 (p. 92).

${ }^{26}$ Hügel, Untersuchungsrichter, Diebsfänger, Detektive.

27 Todd Herzog, 'Crime Stories: Criminal, Society, and the Modernist Case Study', Representations, 80 (2002), 34-61 (42).

${ }^{28}$ Herzog, 'Crime Stories', 56.

${ }^{29}$ Lang also directed the influential Dr Mabuse films, which trace the activities of a criminal mastermind: Dr. Mabuse, der Spieler (1922), Das Testament des Dr. Mabuse (1933) and Die 1000 Augen des Dr. Mabuse (1960).

${ }^{30}$ Horst Lange, 'Nazis vs. the Rule of Law: Allegory and Narrative Structure in Fritz Lang's M', Monatshefte, 101/2 (2009), 170-85 (174).

31 Lang, 'Nazis vs. the Rule of Law', 180-5.

32 See Götting, Der deutsche Kriminalroman zwischen 1945 und 1970, pp. 84-94.

33 Anon., 'Erkaltete Herzen', Der Spiegel, 52 (1983), 115-17.

${ }^{34}$ Volker Weidermann, Das Buch der verbrannten Bücher (Cologne: Kiepenheuer \& Witsch, 2008), pp. 96-8.

35 Carsten Würmann, 'Volksgemeinschaft mit Verbrechen - zum Krimi im Dritten Reich', Krimijahrbuch 2008 (Wupperthal: Nordpark Verlag, 2008), pp. 162-75 (p. 162).

${ }^{36}$ Würmann, 'Zum Kriminalroman im Nationalsozialismus', pp. 152 and 160-2.

37 Carsten Würmann, 'Sternstunden für Mörder: Zur Auseinandersetzung mit der nationalsozialistischen Vergangenheit im Kriminalroman', literaturkritik.de, 9 (2005), http://www.literaturkritik.delpublic/rezension.php?rez_id $=8525$ \&ausgabe $=200509$ (accessed 31 July 2015).

38 Würmann, 'Zum Kriminalroman im Nationalsozialismus', pp. 163-4.

39 Würmann, 'Sternstunden für Mörder'.

${ }^{40}$ Würmann, 'Zum Kriminalroman im Nationalsozialismus', p. 173.

41 Würmann, 'Zum Kriminalroman im Nationalsozialismus', p. 170.

42 Würmann, 'Sternstunden für Mörder' and Irmtraud Götz von Olenhusen, 'Mord Verjährt nicht. Krimis als historische Quelle (1900-1945)', in Korte and Paletschek (eds), Geschichte im Krimi, pp. 105-26 (p. 125).

43 'Es ist das Blut. Das ist die Herkunft. Das schlechte Blut der Sippe.' Cited in Thosaeng Chaochuti, 'What Evil Looked Like: The Practice of Reading the Criminal Body in $19^{\text {th }}$ and $20^{\text {th }}$ Century Europe' (doctoral thesis, University of California, 2008), 123. 
44 See also Susan Tegel, Jew Süss: Life, Legend, Fiction, Film (London: Continuum, 2011).

45 'als Arzt am Volkskörper.' Würmann, 'Sternstunden für Mörder'.

46 James Taylor and Warren Shaw, Dictionary of the Third Reich (London: Penguin, 1997), pp. 155-6.

47 'Der Roman soll nicht nur zeigen, wie effectiv die Ordungsmächte waren, sondern auch die ideologische Linie propagieren, dass "entartete" Menschen schnell und ohne jede Rücksicht ausgerottet werden müssten.' Götz von Olenhusen, 'Mord Verjährt nicht. Krimis als historische Quelle (1900-1945)', p. 126.

48 The novel was based on articles Berthold wrote for the Münchner Illustrierte in 1957, which were also adapted for film (Nachts, wenn der Teufel kam, dir. Robert Siodmak, 1957).

${ }^{49}$ Götting, Der deutsche Kriminalroman zwischen 1945 und 1970, pp. 106-18.

50 'Diesmal ist der . . . Mörder zu spät dran. Andere, vom Staat bezahlte Mörder, sind ihm zuvorgekommen.' Cited in Götting, Der deutsche Kriminalroman zwischen 1945 und 1970, p. 116.

51 Peter Kirschey, 'Das NS-Opfer von Köpenick', neues deutschland, 12 April 2014, http://www.neues-deutschland.delartikel/929909.das-ns-opfer-von-koepenick. html? sstr $=$ Bruno $\% 7 C L \%$ FCdke (accessed 31 July 2015).

52 Würmann, 'Zum Kriminalroman im Nationalsozialismus', p. 143.

53 Barfoot, Frauenkrimi/polar féminin, p. 61 and the Bastei Luebbe website, https://www. luebbe.delbastei-entertainmentlautoren/jerry-cotton/id_2667267 (accessed 31 July 2015).

${ }^{54}$ Lynn M. Kutch and Todd Herzog, 'Introduction', in Lynn M. Kutch and Todd Herzog (eds), Tatort Germany: The Curious Case of German-language Crime Fiction (New York: Camden House, 2014), pp. 1-19 (p. 5).

55 Reinhard Hillich cited in Dorothea Germer, Von Genossen und Gangstern: Zum Gesellschaftsbild in der Kriminaliteratur der DDR und Ostdeutschlands von 1974 bis 1994 (Essen: Verlag Die Blaue Eule, 1998), p. 39.

56 Carol Anne Costabile-Heming, "Der Fall Loest": A Case Study of Crime Stories and the Public Sphere in the GDR', in Kutch and Herzog (eds), Tatort Germany, pp. 139-54 (p. 140).

${ }^{57}$ Germer, Von Genossen und Gangstern, p. 39.

${ }^{58}$ Reinhard Hillich (ed.), Tatbestand. Ansichten zur Kriminalliteratur der DDR 1947-1986 (Berlin: Akademie Verlag, 1989), p. 21.

${ }^{59}$ Germer, Von Genossen und Gangstern, p. 44

${ }^{60}$ Brönnimann, Der Soziokriminalroman, p. 50.

${ }^{61}$ See Olaf Berwald, An Introduction to the Works of Peter Weiss (New York: Camden House, 2003), pp. 22-32.

${ }^{62}$ The imprint published 1,353 titles from 1962 to 2000, producing over 30 million copies. See http://www.rowohlt.de (accessed 31 July 2015).

${ }^{63}$ Brönnimann, Der Soziokriminalroman, p. 18. The Beck series was also published in the GDR, as its critique of capitalism dovetailed with East German views.

${ }^{64}$ Brönnimann, Der Soziokriminalroman, p. 50.

${ }_{65}$ Brönnimann, Der Soziokriminalroman, pp. 54-5.

${ }^{66}$ Brönnimann, Der Soziokriminalroman, pp. 55 and 50.

67 'Das Verbrechen sollte nicht als individuelle Tat betrachtet werden, sondern als direkte, negative Folge gesellschaftlicher Umstände', Brönnimann, Der Soziokriminalroman p. 50 .

68 Brönnimann, Der Soziokriminalroman, pp. 60-9. 
69 Barfoot, Frauenkrimi/polar féminin, pp. 70-1.

70 See Achim Saupe, 'Der NS-Täter als Psychopath', in Achim Saupe, Der Historiker als Detektiv - der Detektiv als Historiker. Historik, Kriminalistik und der Nationalsozialismus als Kriminalroman (Bielefeld: Transcript, 2009), pp. 395-400.

71 Robert C. Conard, Understanding Heinrich Böll (Columbia: University of South Carolina Press, 1992), p. 120.

72 Julian Preece, Baader-Meinhof and the Novel: Narratives of the Nation/Fantasies of the Revolution 1970-2010 (New York: Palgrave MacMillan, 2012), pp. 99-100.

73 Germer, Von Genossen und Gangstern, p. 47.

74 Germer, Von Genossen und Gangstern, p. 48.

75 Germer, Von Genossen und Gangstern, p. 49.

76 See Costabile-Heming, "Der Fall Loest"”.

77 Germer, Von Genossen und Gangstern, pp. 51-3.

${ }^{78}$ Germer, Von Genossen und Gangstern, p. 52.

79 'Kriminalliteratur wird . . . indirekt zur Chronistin des Niedergangs der DDR.' Ibid., p. 53.

${ }^{80}$ Mary Fulbrook, History of Germany 1918-2000: The Divided Nation (2nd edn; Oxford: Blackwell, 2002), p. 162

${ }^{81}$ Leslie A. Adelson, The Turkish Turn in Contemporary German Literature (annotated edn; London: Palgrave Macmillan: 2005), p. 140.

82 Tom Cheesman, Novels of Turkish-German Settlement: Cosmopolite Fictions (New York: Camden House, 2007), p. 84.

${ }^{83}$ Cheesman, Novels of Turkish-German Settlement, p. 157.

${ }^{84}$ See Teraoka, 'Detecting Ethnicity: Jakob Arjouni and the Case of the Missing German Detective Novel'.

85 A film adaptation of Happy Birthday, Türke! was released in 1992 (dir. Doris Dörrie, EuroVideo, 2005).

${ }^{86}$ Cheesman, Novels of Turkish-German Settlement, pp. 88-9.

87 Jim Jordan, 'Of Fables and Multiculturalism: The Felidae novels of Akif Pirinçci', in Arthur Williams, Stuart Parkes and Julian Preece (eds), German-language Literature Today: International and Popular? (Bern and Oxford: Peter Lang, 2000), pp. 255-68.

88 Jordan, 'Of Fables and Multiculturalism', p. 226.

89 Jordan, 'Of Fables and Multiculturalism', p. 263. An animated version of Felidae is available in German and English (dir. Michael Schaak, UFA, 2004).

${ }^{90}$ Wallace, 'Murder in the Weimar Republic: Prejudice, Politics and the Popular in the Socialist Crime Fiction of Hermynia Zur Mühlen', p. 93.

91 Wallace, 'Murder in the Weimar Republic', p. 93.

92 Brigitte Frizzoni, Verhandlungen mit Mordsfrauen. Geschlechterpositionierungen im "Frauenkrimi”" (Zurich: Chronos Verlag, 2009), p. 10.

93 Sascha Gerhards, 'Krimi Quo Vadis: Literary and Televised Trends in the German Crime Genre', in Kutch and Herzog (eds), Tatort Germany, pp. 41-60 (p. 56).

94 'dass Kölner Krimis für Münchener Krimi-Fans kaum noch attraktiv sind.' Ralf Koss, 'Spielart der Freiheit. Kurze Geschichte des neuen deutschen Kriminalromans', Der Spiegel, 10 (1995), http://www.spiegel.delspiegellspiegelspecialld-9259296.html (accessed 31 July 2015).

${ }^{5}$ Christine Lehmann, 'Doch die Idylle trügt: Über Regionalkrimis', Das Argument, 278 (2008), 517-31 (517).

${ }^{96}$ Lehmann, 'Doch die Idylle trügt', 517 and 518.

${ }^{97}$ Lehmann, 'Doch die Idylle trügt', 526. 
98 'wird im besseren Fall Teil einer Heimatfolklore, im schlechteren fällt er zurück in den Provizialismus.' Koss, 'Spielart der Freiheit. Kurze Geschichte des neuen deutschen Kriminalromans'.

${ }^{99}$ See Susanne C. Knittel, 'Case Histories: The Legacy of Nazi Euthanasia in Recent German Heimatkrimis', in Kutch and Herzog (eds), Tatort Germany, pp. 120-38.

${ }^{100}$ Their author website illustrates how local dialect and imagery can be exploited for publishing ends, while promoting tourism in the region: see http://klufti.de/ (accessed 31 July 2015).

${ }^{101}$ Lynn M. Kutch and Todd Herzog, 'Introduction', in Kutch and Herzog (eds), Tatort Germany, p. 10.

${ }^{102}$ Tobias Gohlis, 'Murder and Manslaughter in Germany', http://www.goethe.delkue/lit/ thm/en26884 (accessed 31 July 2015).

${ }^{103}$ See http://www.new-books-in-german.com/english/home/-/273,273,129002, liste9.html (accessed 31 July 2015). New Books in German promotes German-language literature to publishers and readers in the English-speaking world and frequently showcases crime fiction from Austria, Germany and Switzerland.

104 'Was mich fasziniert hat, war genau diese unglaublich seltene Mischung: ein ästhetisches Konzept, das konsequent E-Literatur bedeutet, kombiniert mit einem originellen KrimiKonzept, das beste U-Literatur ist. Wenn so eine Kombination gelingt, haben wir es im Grunde mit einer eigenen Gattung zu tun: EU-Literatur.' Joachim Feldmann, 'Interview mit Simon Urban', CULTurMAG, 27 August 2011, http://culturmag.de/rubriken/buecher/ ein-gesprach-mit-dem-schriftsteller-simon-urban/32414 (accessed 31 July 2015).

${ }^{105}$ See Laurence Roth, Inspecting Jews: American Jewish Detective Stories (New Brunswick: Rutgers University Press, 2004).

${ }^{106}$ Anna-Dorothea Ludewig (ed.), Im Anfang war der Mord: Juden und Judentum im Detektivroman (Berlin: be.bra Verlag, 2012).

${ }^{107}$ Cheesman, Novels of Turkish-German Settlement, p. 92.

\section{Select bibliography}

Arjouni, Jakob, Happy Birthday, Türke! (Zurich: Diogenes, 1987 [1985]). Happy Birthday, Turk! (Harpenden: No Exit Press, 2005).

Berndorff, Hans Rudolf, Shiva und die Galgenblume (Berlin: Hillger, 1943).

Berthold, Will, Nachts, wenn der Teufel kam: Roman nach Tatsachen (Bad Wörishofen: Aktueller Buchverlag, 1959).

Bosetzky, Horst, Einer von uns beiden (Berlin: Rowohlt, 1972).

Costin Wagner, Jan, Das Schweigen (Frankfurt a. M.: Eichborn, 2007). Silence, trans. Anthea Bell (London: Vintage, 2011).

Hey, Richard, Ein Mord am Lietzensee (Munich: Piper, 1998 [1973]).

Hilsenrath, Edgar, Der Nazi und der Friseur (Munich: dtv, 2006 [1977]). The Nazi and the Barber, trans. Andrew White (Berlin: Barber Press, 2013).

Kästner, Erich, Emil und die Detektive (Hamburg: Dressler, 2010 [1929]). Emil and the Detectives, trans. Eileen Hall (London: Vintage Classics, 2012).

Lang, Fritz (dir.), M - eine Stadt sucht einen Mörder (StudioCanal, 2009 [1931]).

Lernet-Holenia, Alexander, Ich war Jack Mortimer (Munich: Droemer Knaur, 1985 [1933]). Noll, Ingrid, Die Apothekerin (Zurich: Diogenes, 1996 [1994]). The Pharmacist (London: HarperCollins, 1995). 
Ören, Aras, Bitte nix Polizei: Kriminalerzählung (Düsseldorf: Claassen, 1994 [1981]).

Pirinçci, Akif, Felidae (Munich: Goldmann, 1989). Felidae. A Novel of Cats and Murder (New York: Sage, 1993).

Rodrian, Irene, Küsschen für den Totengräber (Hamburg: Rowohlt, 1974).

Sanzara, Rahel, Das verlorene Kind - Ein Krimi-Klassiker von Johanna Bleschke (e-artnow, 2014 [1926]).

Süskind, Patrick, Das Parfum - Die Geschichte eines Mörders (Zurich: Diogenes, 1994 [1985]). Perfume - The Story of a Murderer, trans. John E. Woods (London: Penguin, 2010).

Turhan, Su, Kommissar Pascha. Ein Fall für Zeki Demirbilek (Munich: Knaur, 2013).

Walther, J. Monika, Goldbroiler oder die Beschreibung einer Schlacht: Kriminalgeschichte (Klagenfurt: Verlag Orange Cursor, 2013 [2009]).

\section{Further secondary reading}

See the annotated bibliography at the end of this volume. 


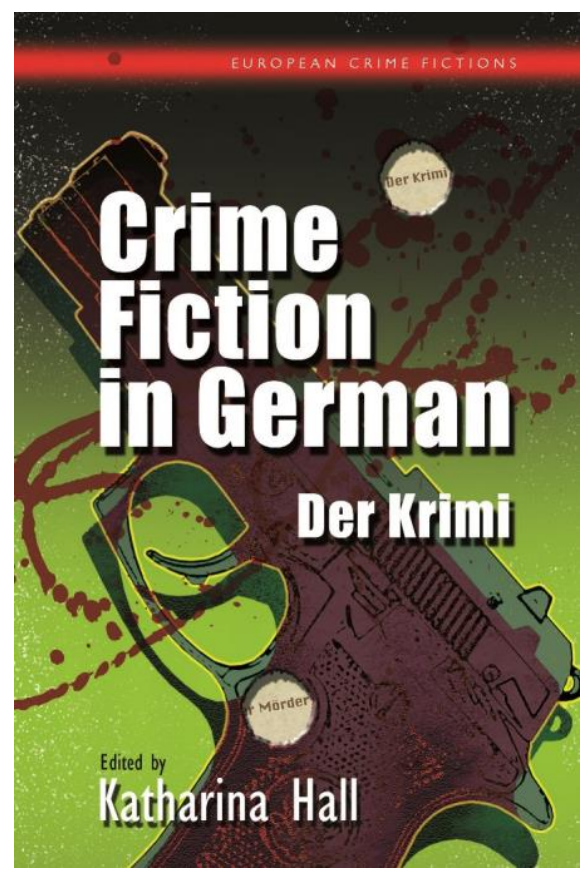

The full text of Crime Fiction in German: Der Krimi is available to purchase in print and electronic formats from the University of Wales Press website: http://www.uwp.co.uk/editions/9781783168170 